\title{
Epidural Steroids in the Management of Chronic Spinal Pain AND RADICULOPATHY
}

Mark V. Boswell, MD,PhD*, Hans C. Hansen, MD\#, Andrea M. Trescot, MD**, and Joshua A. Hirsch, MD\#\#

Epidural injections with or without steroids are used extensively in the management of chronic spinal pain. However, evidence is contradictory with continuing debate about the value of epidural steroid injections in chronic spinal syndromes.

The objective of this systematic review is to determine the effectiveness of epidural injections in the treatment of chronic spinal pain. Data sources include relevant literature identified through searchs of MEDLINE, EMBASE (Jan 1966- Mar 2003), manual searches of bibliographies of known primary and review articles, and abstracts from scientific meetings. Both randomized and non-

Lifetime prevalence of spinal pain has been reported as $65 \%$ to $80 \%$ in the neck and low back (1-5). After the initial episode, modern evidence has shown that the prevalence of persistent low back and neck pain ranges from $26 \%$ to $75 \%$ (6-17). Patho-anatomic evidence shows that discs can produce pain in the neck and upper extremities; thoracic spine, chest wall and abdominal wall; and low back and lower extremities. Disc related pain is caused by disc degeneration, disc herniation, or by biochemical effects including inflammation. Human intervertebral disc degeneration is a formidable clinical problem and a leading cause of pain and disability, resulting in significant healthcare-related costs (18-22). The degenerative process in intervertebral discs is associated with a series of biochemical and morphologic changes that combine to alter the biomechanical properties of the motion seg-

From *Case Western Reserve University, Cleveland, Ohio, "The Pain Relief Centers, Conover, North Carolina, ${ }^{\star *}$ The Pain Center, Orange Park, Florida, and \#Harvard School of Medicine, Boston, Massachusetts. Address Correspondence: Mark V. Boswell, MD, PhD, 11100 Euclid Avenue, Cleveland, Ohio 44106. E-mail: mark.boswell@uhhs.com

Funding: No external Support was received in completion of this study randomized studies were included in the review based on the criteria established by the Agency for Healthcare Research and Quality (AHRQ). Studies were excluded from the analysis if they were simply review or descriptive and failed to meet minimum criteria.

The results showed that there was strong evidence to indicate effectiveness of transforaminal epidural injections in managing lumbar nerve root pain. Further, evidence was moderate for caudal epidural injections in managing lumbar radicular pain. The evidence in management of chronic neck pain, chronic low back pain, cervical radiculopathy, spinal stenosis, and post laminectomy syn- drome was limited or inconclusive.

In conclusion, the evidence of effectiveness of transforaminal epidural injections in managing lumbar nerve root pain was strong, whereas, effectiveness of caudal epidural injections in managing lumbar radiculopathy was moderate, while there was limited or inconclusive evidence of effectiveness of epidural injections in managing chronic spinal pain without radiculopathy, spinal stenosis, post lumbar laminectomy syndrome, and cervical radiculopathy.

Keywords: Low back pain, epidural steroids, interlaminar, caudal, transforaminal, radiculopathy ment $(18,22-25)$. Disc degeneration with or without disc herniation can cause low back pain (26-30).

Traditionally, compression of nerve roots or dorsal root ganglion by the herniated nucleus pulposus (HNP) has been regarded as the cause of sciatica, but during the past decade, the pivotal role of multiple etiologies has been implicated. Thus, proposed etiologies are not limited to neural compression $(22,26,27)$, but also include vascular compromise (22, 31 ), inflammation (32-35), biochemical and neural mechanisms (18, 36-44), internal disc disruption (45), intraneural and epidural fibrosis (46-50), dural irritation (51), spinal stenosis (52), and inflammation and swelling of dorsal root ganglion (53-55).

Epidural injection of corticosteroids is one of the commonly used interventions in managing chronic spinal pain (5658). Several approaches are available to access the lumbar epidural space: caudal, interlaminar, and transforaminal. Epidural administration of corticosteroids is one of the subjects most studied in interventional pain management with the most systematic reviews available, though highly controversial (59-71). Bogduk et al (57) in 1994, after extensive review, concluded that the balance of the published evidence supports the therapeutic use of caudal epidurals. Bogduk (61) in 1999 supported the potential usefulness of transforaminal steroids for disc prolapse. Bogduk and Govind (72) in 1999 concluded that transforaminal injection of steroids can be entertained with the prospect of achieving substantial and lasting relief of the pain; but if facilities for transforaminal injections are not available, patients might be offered temporizing, palliative therapy by means of caudal injection of steroid and local anesthetic for patients with lumbar radicular pain unresponsive to lesser, conservative measures, and for whom surgery might be the only other option. Bogduk (73) in 1999, in reference to cervical radicular pain concluded that in the interest of helping patients avoid surgery when this is the only other therapeutic option being entertained, a cervical epidural injection of steroids might be offered, or preferably, if facilities are available, a periradicular injection of steroids might be offered. However, both of these recommendations $(72,73)$ apply to acute lumbar and cervical radicular pain. Bogduk and McGuirk (74) in reviewing monotherapy for chronic low back pain (not radicu- 
lar pain) concluded that epidural steroids may be indicated for radicular pain, but they are not indicated for acute back pain and there is no evidence that they are effective for chronic low back pain. Koes et al $(62,63)$ in a systematic review of randomized clinical trials concluded that the efficacy of epidural steroid injections has not yet been established and their benefit, if any, seems to be of short duration only. van Tulder et al $(65,75)$ in 1997 and 2000, concluded that there was conflicting evidence that epidural steroid injections provide better short-term pain relief than placebo for patients with radicular symptoms. Further, they concluded that there was moderate evidence that epidural steroid injections were not effective for chronic low back pain without radicular symptoms. Watts and Silagy (64) in a 1995 meta-analysis, concluded that epidural steroids were effective based on the definition of effectiveness in terms of pain relief (at least a $75 \%$ improvement) in the short-term (60 days) and in the long-term (1 year). McQuay and Moore (68) in 1998 concluded that epidural corticosteroid injections were effective for back pain and sciatica, providing substantial relief for up to 12 weeks, but few patients with chronic spinal pain reported complete relief with majority returning for repeated epidural injections. Nelemans et al (66) in 2001, in a Cochrane review of injection therapy, concluded that epidural steroid injections were not effective in management of chronic low back or radicular pain. Vroomen et al (69) in 2000, in a review of conservative treatment of sciatica, concluded that epidural steroids may be beneficial for subgroups of nerve root compression. Rozenberg et al (70) in 1999 were unable to determine whether epidural steroids are effective in common low back pain and sciatica based on their review. In contrast, Manchikanti et al $(56,58)$ in reviewing the literature in 2001 and 2003, reviewed three types of epidurals separately rather than in combination as the previous reviews. They concluded that there was favorable evidence for caudal epidural steroid injections and transforaminal epidural steroid injections in managing chronic low back pain. There are no systematic reviews available describing pain of cervical or thoracic origin.

Mechanism of action of epidural injections is not well understood. It is believed that neural blockade alters or interrupts nociceptive input, reflex mechanisms of the afferent limb, self-sustaining activity of the neuron pools and neuraxis, and the pattern of central neuronal activities (76). Explanations for improvements are based in part on the pharmacological and physical actions of local anesthetics, corticosteroids, and other agents. It is believed that local anesthetics interrupt the pain-spasm cycle and reverberating nociceptor transmission, whereas corticosteroids reduce inflammation either by inhibiting the synthesis or release of a number of pro-inflammatory substances and by causing a reversible local anesthetic effect (77-90), even though an inflammatory basis for either cervical or radicular pain has not been proven $(72,73)$.

This systematic review was undertaken due to conflicting opinions and inconclusive evidence in the literature. Further, authors strongly believe that due to the inherent variations and differences in the 3 techniques applied in delivery of epidural steroids, previous reviews were not only incomplete, but also inaccurate. Thus, due to variations, differences, advantages, and disadvantages applicable to each technique (including the effectiveness and outcomes), caudal epidural injections; interlaminar epidural injections (cervical, thoracic, and lumbar epidural injections); and transforaminal epidural injections (cervical, thoracic, and lumbosacral) are considered as separate entities within epidural injections and are evaluated as such.

\section{Methods}

\section{Literature Search}

Our literature search included MEDLINE, EMBASE (Jan 1966 - Mar 2003), systematic reviews, narrative reviews,

Table 1. AHRQ's important domains and elements for systems to rate quality of individual articles (91)

\begin{tabular}{|l|l|}
\hline Randomized Clinical Trials & Observational Studies \\
\hline 1. Study question & Study question \\
\hline 2. Study population & Study population \\
\hline 3. Randomization & Comparability of subjects \\
\hline 4. Blinding & \\
\hline 5. Interventions & Exposure or intervention \\
\hline 6. Outcomes & Outcome measurement \\
\hline 7. Statistical analysis & Statistical analysis \\
\hline 8. Results & Results \\
\hline 9. Discussion & Discussion \\
\hline 10. Funding or sponsorship & Funding or sponsorship \\
\hline
\end{tabular}

cross-references to the reviews and various published trials; and peer reviewed abstracts from scientific meetings during the past two years. The search strategy consisted of diagnostic interventional techniques, epidural injections and steroids, transforaminal epidurals, nerve root blocks, and caudal epidural steroids, with emphasis on chronic pain/low back pain/neck pain/mid back or thoracic pain or spinal pain.

\section{Selection Criteria}

The review focused on randomized and non-randomized evaluations. The population of interest was patients suffering with chronic spinal pain for at least 3 months. Three types of epidural injections with local anesthetic, steroid, or other drugs, provided for management of spinal pain were evaluated. All the studies providing appropriate management with outcome evaluations of 3 months and statistical evaluations were reviewed. The primary outcome measure was pain relief at various points. The secondary outcome measures were functional status improvement and complications.

For evaluating the quality of individual articles, we have used the criteria from the Agency for Healthcare Research and Quality (AHRQ) publication (91). This document described important domains and elements for randomized and nonrandomized trials as shown in Table 1.

\section{Data Extraction}

Study evaluation and inclusion and exclusion algorithmic approach is shown in Table 2. Methodologic quality assessment was performed as described in Table 1. A score of 4 or more of 7 for randomized trials and a score of 3 or more 
Table 2. Study evaluation (inclusion/exclusion) algorithm

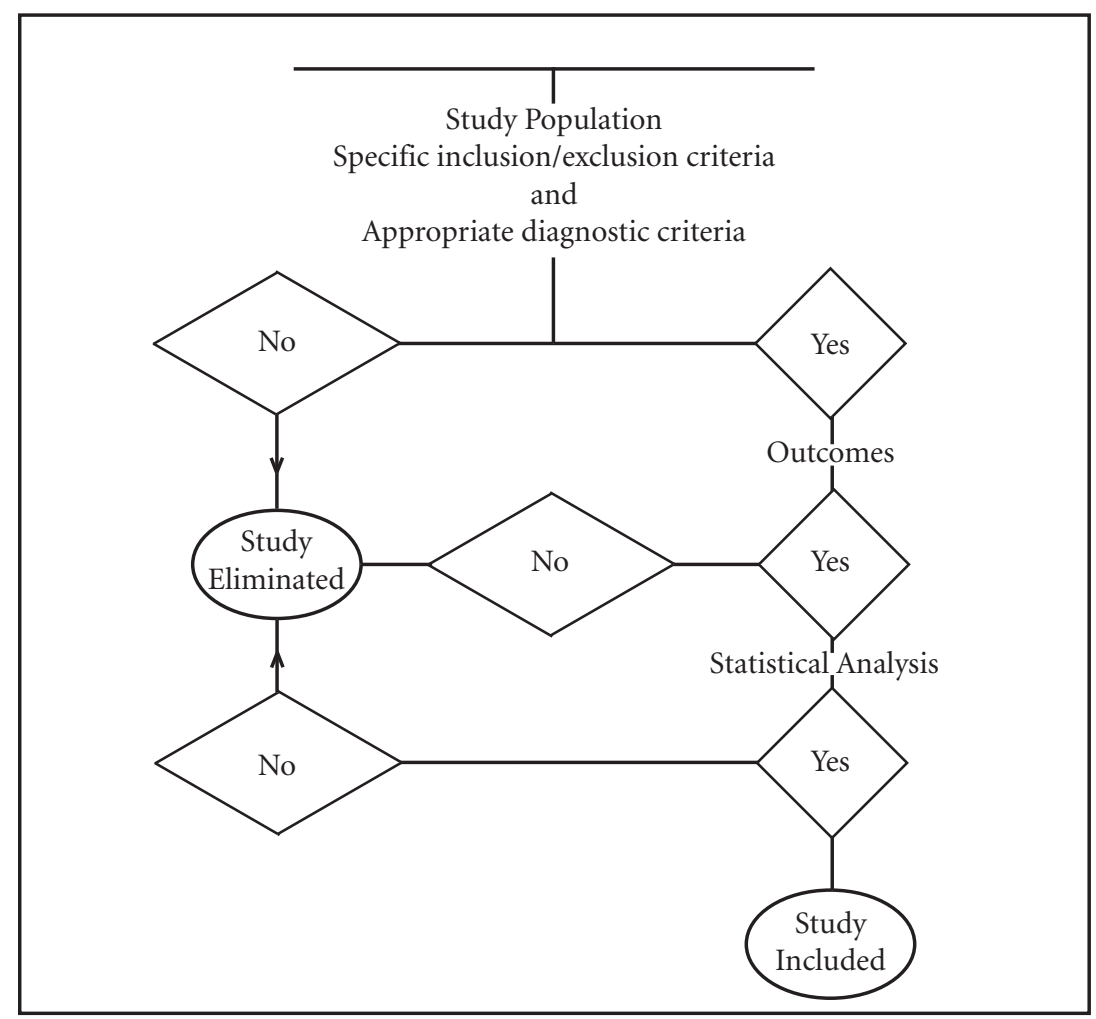

of 5 was required to meet inciusion criteria. Studies were also eliminated if there were no appropriate outcomes of at least 3 months or statistical analysis.

Modified quality abstraction forms described by AHRQ were utilized. All the potential studies were evaluated by the 3 authors. Any disagreements were resolved by consensus.

\section{Qualitative Analysis}

Qualitative analysis was conducted, using five levels of evidence for effectiveness of epidural steroids as illustrated

\section{Table 3. Designation of levels of evidence}

Level I- Conclusive: Research-based evidence with multiple relevant and high-quality scientific studies or consistent reviews of meta-analyses.

Level II - Strong: Research-based evidence from at least one properly designed randomized, controlled trial of appropriate size (with at least 60 patients in smallest group); or research-based evidence from multiple properly designed studies of smaller size; or at least one randomized trial, supplemented by predominantly positive prospective and/or retrospective evidence.

Level III - Moderate: Evidence from a well-designed small randomized trial or evidence from well-designed trials without randomization, or quasi-randomized studies, single group, pre-post cohort, time series, or matched case-controlled studies or positive evidence from at least one meta-analysis.

Level IV - Limited: Evidence from well-designed nonexperimental studies from more than one center or research group

Level V - Indeterminate: Opinions of respected authorities, based on clinical evidence, descriptive studies, or reports of expert committees.
RESULTS

\section{Caudal Epidural Injections}

Multiple reports studying caudal epidural injections included 8 randomized or double blind trials (92-99), 4 prospective trials (100-103), and multiple retrospective evaluations (104-107). The results of published reports of the randomized trials are described in Table 4, while Table 5 shows description of non-randomized trials (prospective and retrospective).

Of the 8 randomized or double blind trials, 2 trials were excluded. One study was excluded (96), due to non-availability of analyzable information. A second trial (95) was excluded due to lack of data at 3 months. Of the remaining 6 trials, 4 were positive for short-term pain relief (92, $93,97,98)$, and 4 were positive for longterm relief $(92,94,97,98)$. Among the 4 prospective trials (100-103) and 4 retrospective trials (104-107) meeting inclusion criteria, all were positive for shortterm and long-term relief with multiple injections.

Among 6 randomized trials included for analyses (92-94, 97-99), only 3 studied predominantly patients with radiculopathy or sciatica (92-94), 2 studied post lumbar laminectomy syndrome $(98,99)$, and 1 studied mixed population (97). Of the 3 trials evaluating predominantly radiculopathy, 2 were positive ( 92 , 93) and one study was negative (94) for short-term relief, whereas 2 of 3 were positive for long-term relief $(92,94)$. Among two studies with postlumbar laminectomy syndrome $(98,99)$, only one study (98) was positive in short-term and longterm. None of the studies included only the patients with chronic low back pain.

Among the non-randomized evaluations, including retrospective studies, four (102-104, 106) of eight (100-107) included patients with radicular pain or sciatica, all showing positive results. Three studies essentially included patients with chronic low back pain without demonstrated radicular pain $(100,101,105)$. One study (107) evaluated the patients with lumbar canal stenosis.

\section{Interlaminar Epidural Injections}

Multiple studies evaluating the effectiveness of interlaminar epidural injections, specifically the lumbar epidural injections included 16 randomized or double blind trials (108-123), 8 nonrandomized prospective trials (124-131), 
Table 4. Characteristics of published randomized trials of caudal epidural injections

\begin{tabular}{|c|c|c|c|c|c|}
\hline Study/Methods & Participants & Interventions & Outcomes & Results & $\begin{array}{l}\text { Outcomes/ } \\
\text { Conclusion }\end{array}$ \\
\hline $\begin{array}{l}\text { Breivik et al (92) } \\
\text { Randomized } \\
\text { double blind trial. } \\
\text { Randomization } \\
\text { according to a } \\
\text { list of random } \\
\text { numbers. } \\
\text { Parallel, cohort } \\
\text { design }\end{array}$ & $\begin{array}{l}35 \text { patients with } \\
\text { incapacitating } \\
\text { chronic low back pain } \\
\text { and sciatica. } \\
\text { Diagnosis based } \\
\text { on radiculopathy: } \\
\text { arachnoiditis }(n=8) \text {, } \\
\text { no abnormality } \\
(n=11) \text {, inconclusive } \\
\text { findings ( } n=5) \text {. } \\
\text { Duration: several } \\
\text { months to several } \\
\text { years. }\end{array}$ & $\begin{array}{l}\text { Caudal epidural injection: } \\
\text { Experimental: } 20 \mathrm{~mL} \\
\text { bupivacaine } 0.25 \% \text { with } 80 \\
\text { mg depomethylprednisone } \\
\text { ( } \mathrm{n}=16 \text { ) } \\
\text { Placebo: } 20 \mathrm{~mL} \text { bupivacaine } \\
0.25 \% \text { followed by } 100 \mathrm{~mL} \\
\text { saline ( } \mathrm{n}=19 \text { ). } \\
\text { Frequency: up to three } \\
\text { injections at weekly intervals. }\end{array}$ & $\begin{array}{l}\text { Timing: not mentioned. } \\
\text { Outcome measures: } \\
\text { 1. Pain relief: } \\
\text { significant diminution of } \\
\text { pain and/or paresis to } \\
\text { a degree that enabled } \\
\text { return to work. } \\
\text { 2. Objective } \\
\text { improvement: sensation, } \\
\text { Lasègue's test, paresis, } \\
\text { spinal reflexes, and } \\
\text { sphincter disorders. }\end{array}$ & $\begin{array}{l}56 \% \text { of the patients } \\
\text { reported considerable } \\
\text { pain relief in experimental } \\
\text { group compared to } 26 \% \text { of } \\
\text { the patients in the placebo } \\
\text { group. }\end{array}$ & $\begin{array}{l}\text { Positive } \\
\text { short-term } \\
\text { and long- } \\
\text { term relief }\end{array}$ \\
\hline $\begin{array}{l}\text { Bush and Hillier } \\
\text { (93) } \\
\text { Randomized double } \\
\text { blind trial. } \\
28 \text { patients were } \\
\text { randomized; only } \\
23 \text { patients were } \\
\text { entered into the } \\
\text { study. }\end{array}$ & $\begin{array}{l}23 \text { patients with } \\
\text { lumbar nerve root } \\
\text { compromise. } \\
\text { Mean duration } \\
\text { (range) in } \\
\text { experimental group: } \\
5.8 \text { months (1-13 } \\
\text { months) and in } \\
\text { control group } 4.7 \\
\text { months (1-12). }\end{array}$ & $\begin{array}{l}\text { Caudal epidural injections: } \\
\text { Experimental: } 25 \mathrm{~mL}: \\
80 \mathrm{mg} \text { triamcinolone } \\
\text { acetonide }+0.5 \% \text { procaine } \\
\text { hydrochloride }(\mathrm{n}=12) \\
\text { Control: } 25 \mathrm{~mL} \text { normal saline } \\
\text { ( } \mathrm{n}=11) \\
\text { Frequency: two caudal } \\
\text { injections, the first after } \\
\text { admission to the trial and a } \\
\text { second after } 2 \text { weeks }\end{array}$ & $\begin{array}{l}\text { Timing: four weeks and } \\
\text { at one year. } \\
\text { Outcome measures: } \\
\text { 1. Effect on lifestyle. } \\
\text { 2. Back and leg pain } \\
\text { 3. Angle of positive SLR. }\end{array}$ & $\begin{array}{l}\text { Significantly better results } \\
\text { with pain and straight leg } \\
\text { raising in experimental } \\
\text { group in short-term. } \\
\text { Pain not significantly } \\
\text { different but straight leg } \\
\text { raise significantly better } \\
\text { for long-term relief. }\end{array}$ & $\begin{array}{l}\text { Positive } \\
\text { short-term } \\
\text { relief and } \\
\text { negative } \\
\text { long-term } \\
\text { relief }\end{array}$ \\
\hline $\begin{array}{l}\text { Matthews et al (94) } \\
\text { Double blind. } \\
\text { Stratification by } \\
\text { age and gender. } \\
\text { Survival curve } \\
\text { analyses based on } \\
\text { cumulative totals } \\
\text { recovered. }\end{array}$ & $\begin{array}{l}57 \text { patients with } \\
\text { sciatica with a single } \\
\text { root compression } \\
\text { Experimental group: } \\
\text { male/female: } 19 / 4 \text {, } \\
\text { median duration of } \\
\text { pain: } 4 \text { weeks (range: } \\
8 \text { days-3 months). } \\
\text { Control group: } \\
\text { male/female: } 24 / 10 \text {, } \\
\text { median duration of } \\
\text { pain: } 4 \text { weeks (range: } \\
3 \text { days-9 weeks). }\end{array}$ & $\begin{array}{l}\text { Caudal epidural injections: } \\
\text { Experimental: } 20 \mathrm{~mL} \\
\text { bupivacaine } 0.125 \%+2 \mathrm{~mL} \\
\text { (80 mg) methylprednisolone } \\
\text { acetate }(\mathrm{n}=23) \text {. } \\
\text { Control: } 2 \mathrm{~mL} \text { lignocaine } \\
\text { (over the sacral hiatus or into } \\
\text { a tender spot) ( } \mathrm{n}=34) \\
\text { Frequency: fortnightly } \\
\text { intervals, up to three times } \\
\text { as needed }\end{array}$ & $\begin{array}{l}\text { Timing: } 2 \text { weeks, } 1,3,6 \text {, } \\
\text { and } 12 \text { months. } \\
\text { Outcome measures: } \\
\text { 1. Pain (recovered vs not } \\
\text { recovered). } \\
\text { 2. Range of movement } \\
\text { 3. Straight leg raising } \\
\text { 4. Neurologic } \\
\text { examination }\end{array}$ & $\begin{array}{l}\text { There was no significant } \\
\text { difference between } \\
\text { experimental and control } \\
\text { group with short-term } \\
\text { relief ( } 67 \% \text { vs } 56 \%) \text {. } \\
\text { After } 3 \text { months, patients } \\
\text { in experimental group } \\
\text { reported significantly more } \\
\text { pain-free than in control } \\
\text { group. }\end{array}$ & $\begin{array}{l}\text { Negative } \\
\text { short-term } \\
\text { relief and } \\
\text { positive } \\
\text { long-term } \\
\text { relief }\end{array}$ \\
\hline $\begin{array}{l}\text { Helsa and Breivik } \\
(97) \\
\text { Double blind trial } \\
\text { with crossover } \\
\text { design }\end{array}$ & $\begin{array}{l}69 \text { patients with } \\
\text { incapacitating } \\
\text { chronic low back pain } \\
\text { and sciatica. } \\
36 \text { of } 69 \text { previously } \\
\text { been operated on for } \\
\text { herniated disc. }\end{array}$ & $\begin{array}{l}\text { Three caudal epidural } \\
\text { injections of either } \\
\text { bupivacaine with } \\
\text { depomethylprednisolone } \\
80 \text { mg or with bupivacaine } \\
\text { followed by normal saline. } \\
\text { If no improvement had } \\
\text { occurred after } 3 \text { injections, a } \\
\text { series of the alternative type } \\
\text { of injection was given. }\end{array}$ & $\begin{array}{l}\text { Timing: not mentioned. } \\
\text { Outcome measures: } \\
\text { significant improvement } \\
\text { to return to work or to } \\
\text { be retrained for another } \\
\text { occupation }\end{array}$ & $\begin{array}{l}\text { i. } 34 \text { of the } 58 \text { patients } \\
(59 \%) \text { receiving caudal } \\
\text { epidural injections } \\
\text { of bupivacaine and } \\
\text { depomethylprednisolone } \\
\text { showed significant } \\
\text { improvement. } \\
\text { ii. } 12 \text { of } 49 \text { patients ( } 25 \%) \\
\text { who received bupivacaine } \\
\text { followed by saline were } \\
\text { improved. }\end{array}$ & $\begin{array}{l}\text { Positive } \\
\text { short-term } \\
\text { and long- } \\
\text { term relief }\end{array}$ \\
\hline $\begin{array}{l}\text { Revel et al (98) } \\
\text { Randomized trial. }\end{array}$ & $\begin{array}{l}60 \text { post lumbar } \\
\text { laminectomy patients } \\
\text { with chronic low back } \\
\text { pain }\end{array}$ & $\begin{array}{l}\text { Forceful caudal injection: } \\
\text { Experimental: } 125 \mathrm{mg} \text { of } \\
\text { prednisolone acetate with } \\
40 \mathrm{~mL} \text { of normal saline in the } \\
\text { treatment group. } \\
\text { Control: } 125 \mathrm{mg} \text { of } \\
\text { prednisolone in the control } \\
\text { group. }\end{array}$ & $\begin{array}{l}\text { Timing: } 6 \text { months. } \\
\text { Outcome measures: pain } \\
\text { relief. }\end{array}$ & $\begin{array}{l}\text { The proportion of patients } \\
\text { relieved of sciatica was } \\
49 \% \text { in the forceful } \\
\text { injection group compared } \\
\text { to } 19 \% \text { in the control group } \\
\text { with significant difference. }\end{array}$ & $\begin{array}{l}\text { Positive } \\
\text { short-term } \\
\text { and long- } \\
\text { term relief }\end{array}$ \\
\hline $\begin{array}{l}\text { Meadeb et al (99) } \\
\text { Randomized trial. } \\
\text { Parallel-group } \\
\text { study. }\end{array}$ & $\begin{array}{l}47 \text { post lumbar } \\
\text { laminectomy } \\
\text { syndrome patients in } \\
\text { a multicenter study. }\end{array}$ & $\begin{array}{l}\text { Experimental group: forceful } \\
\text { injection of } 20 \text { mL of normal } \\
\text { saline with or without } 125 \\
\text { mg of epidural prednisolone } \\
\text { acetate. } \\
\text { Control group: } 125 \mathrm{mg} \text { of } \\
\text { epidural prednisolone. } \\
\text { Frequency: each of the } 3 \\
\text { treatments were provided } \\
\text { once a month for } 3 \\
\text { consecutive months. }\end{array}$ & $\begin{array}{l}\text { Timing: day } 1 \text {, day } 30 \\
\text { and day } 120 . \\
\text { Outcome measures: } \\
\text { visual analog scores. }\end{array}$ & $\begin{array}{l}\text { The VAS scores improved } \\
\text { steadily in the forceful } \\
\text { injection group, producing } \\
\text { a nonsignificant difference } \\
\text { on day } 120 \text { as compared to } \\
\text { the baseline (day } 30=120 \\
\text { days). }\end{array}$ & $\begin{array}{l}\text { Negative } \\
\text { short-term } \\
\text { and long- } \\
\text { term relief }\end{array}$ \\
\hline
\end{tabular}


Table 5. Characteristics and results of non-randomized studies of caudal epidural injections

\begin{tabular}{|c|c|c|c|c|c|}
\hline $\begin{array}{l}\text { Study/ } \\
\text { Methods }\end{array}$ & Participants & Interventions & Outcomes & Results & $\begin{array}{l}\text { Outcomes/ } \\
\text { Conclusion }\end{array}$ \\
\hline $\begin{array}{l}\text { Yates (102) } \\
\text { Prospective } \\
\text { evaluation }\end{array}$ & $\begin{array}{l}20 \text { patients with low } \\
\text { back pain and sciatica. }\end{array}$ & $\begin{array}{l}\text { Group I: } 60 \mathrm{mg} \text { of triamcinolone } \\
\text { (3 mL + } 47 \mathrm{~mL} \text { normal saline) } \\
\text { Group II: } 60 \mathrm{mg} \text { of triamcinolone } \\
\text { (3 } \mathrm{mL}+47 \mathrm{~mL} \text { lignocaine } 0.5 \% \text { ) } \\
\text { Group III: } 50 \mathrm{~mL} \text { saline } \\
\text { Group IV: } 50 \mathrm{~mL} \text { lignocaine } \\
\text { Injections were given at weekly } \\
\text { intervals in a random order }\end{array}$ & $\begin{array}{l}\text { Timing not mentioned. } \\
\text { Subjective and objective } \\
\text { criteria of progress. } \\
\text { Study did not address } \\
\text { pain-relief. } \\
\text { Study focused on } \\
\text { improvement in straight } \\
\text { leg raising which seemed } \\
\text { to correlate with pain- } \\
\text { relief. }\end{array}$ & $\begin{array}{l}\text { Greatest improvement } \\
\text { was noted after the } \\
\text { injection containing } \\
\text { steroid. } \\
\text { The results suggested } \\
\text { that the action of a } \\
\text { successful epidural } \\
\text { injection is primarily } \\
\text { anti-inflammatory } \\
\text { and to a lesser extent, } \\
\text { hydrodynamic. }\end{array}$ & $\begin{array}{l}\text { Positive } \\
\text { short-term } \\
\text { and long- } \\
\text { term relief. }\end{array}$ \\
\hline $\begin{array}{l}\text { Waldman } \\
\text { (103) } \\
\text { Prospective } \\
\text { evaluation } \\
\text { with } \\
\text { independent } \\
\text { observer } \\
\text { review. }\end{array}$ & $\begin{array}{l}53 \text { patients meeting } \\
\text { stringent inclusion } \\
\text { criteria with radicular } \\
\text { pain distribution } \\
\text { anatomically } \\
\text { correlating with } \\
\text { documented disc } \\
\text { herniation and nerve } \\
\text { root impingement. }\end{array}$ & $\begin{array}{l}\text { Treatment: } 7.5 \mathrm{~mL} \text { of } 1 \% \\
\text { lidocaine and } 80 \mathrm{mg} \text { of } \\
\text { methylprednisolone with } \\
\text { the first block and } 40 \mathrm{mg} \text { of } \\
\text { methylprednisolone with } \\
\text { subsequent blocks. } \\
\text { Subsequent blocks were } \\
\text { repeated in } 48 \text { to } 72 \text { hour } \\
\text { intervals with the end point } \\
\text { being complete pain relief or } 4 \\
\text { caudal epidural blocks. }\end{array}$ & $\begin{array}{l}\text { Timing: } 6 \text { weeks, } 3 \\
\text { months, } 6 \text { months. } \\
\text { Visual analog scale and } \\
\text { verbal analog scores. }\end{array}$ & $\begin{array}{l}\text { Combined visual analog } \\
\text { scale and verbal analog } \\
\text { scores for all patients } \\
\text { were reduced } 63 \% \text { at } 6 \\
\text { weeks, } 67 \% \text { at } 3 \text { months, } \\
\text { and } 71 \% \text { at } 6 \text { months. }\end{array}$ & $\begin{array}{l}\text { Positive } \\
\text { short-term } \\
\text { and long- } \\
\text { term relief. }\end{array}$ \\
\hline $\begin{array}{l}\text { Manchikanti } \\
\text { et al (100) } \\
\text { A randomized } \\
\text { trial with } \\
\text { convenient } \\
\text { control } \\
\text { group. }\end{array}$ & $\begin{array}{l}70 \text { patients after } \\
\text { failed conservative } \\
\text { management with } \\
\text { physical therapy, } \\
\text { chiropractic and } \\
\text { medication therapy. } \\
\text { All patients were } \\
\text { shown to be negative } \\
\text { for facet joint pain. }\end{array}$ & $\begin{array}{l}\text { Caudal epidural injections: } \\
\text { Group I : no treatment } \\
\text { Group II: local anesthetic and } \\
\text { Sarapin total of } 20 \mathrm{~mL} \text { with } 10 \\
\mathrm{~mL} \text { each. } \\
\text { Group III: } 10 \mathrm{~mL} \text { of local } \\
\text { anesthetic and } 6 \mathrm{mg} \text { of } \\
\text { betamethasone }\end{array}$ & $\begin{array}{l}\text { Timing: } 2 \text { weeks, } 1 \\
\text { month, } 3 \text { months, } 6 \\
\text { months and } 1 \text { year. } \\
\text { Outcome measures: } \\
\text { Average pain, physical } \\
\text { health, mental health, } \\
\text { and functional status }\end{array}$ & $\begin{array}{l}\text { Average pain, physical } \\
\text { health, mental health, } \\
\text { functional status, narcotic } \\
\text { intake and employment } \\
\text { improved significantly } \\
\text { in Group II and Group III } \\
\text { at } 2 \text { weeks, } 1 \text { month, } 3 \\
\text { months, } 6 \text { months and } \\
1 \text { year. }\end{array}$ & $\begin{array}{l}\text { Positive } \\
\text { short-term } \\
\text { and long- } \\
\text { term relief. }\end{array}$ \\
\hline $\begin{array}{l}\text { Manchikanti } \\
\text { et al (101) } \\
\text { Prospective } \\
\text { evaluation in } \\
\text { discogram- } \\
\text { positive and } \\
\text { discogram- } \\
\text { negative } \\
\text { chronic low } \\
\text { back pain } \\
\text { patients. }\end{array}$ & $\begin{array}{l}62 \text { patients were } \\
\text { evaluated. } \\
\text { Negative provocative } \\
\text { discography: } 45 \\
\text { patients } \\
\text { Positive provocative } \\
\text { discography: } 17 \\
\text { patients }\end{array}$ & $\begin{array}{l}\text { Caudal epidural injections (1-3) } \\
\text { with or without steroids. }\end{array}$ & $\begin{array}{l}\text { Timing: } 1 \text { month, } 3 \\
\text { months, and } 6 \text { months. } \\
\text { Average pain, physical } \\
\text { health, mental health, } \\
\text { functional status, } \\
\text { psychological status, } \\
\text { symptom magnification, } \\
\text { narcotic intake and } \\
\text { employment status. }\end{array}$ & $\begin{array}{l}69 \% \text { of the patients in } \\
\text { the negative discography } \\
\text { group and } 65 \% \text { of the } \\
\text { patients in the positive } \\
\text { discography group were in } \\
\text { successful category. } \\
\text { Comparison of } \\
\text { overall health status, } \\
\text { psychological status, } \\
\text { narcotic intake and } \\
\text { return to work showed } \\
\text { significant improvement in } \\
\text { successful category. }\end{array}$ & $\begin{array}{l}\text { Positive } \\
\text { short-term } \\
\text { and long- } \\
\text { term relief. }\end{array}$ \\
\hline $\begin{array}{l}\text { Hauswirth } \\
\text { and Michot } \\
\text { (104) } \\
\text { Retrospective } \\
\text { evaluation }\end{array}$ & $\begin{array}{l}75 \text { patients with } \\
\text { chronic low back pain } \\
\text { and sciatica }\end{array}$ & $\begin{array}{l}\text { Caudal epidural injections of } \\
\text { local anesthetic and steroids }\end{array}$ & $\begin{array}{l}\text { Timing: not mentioned } \\
\text { Outcome measures: pain } \\
\text { relief }\end{array}$ & $\begin{array}{l}\text { Results were excellent in } \\
60 \% \text { and good in } 24 \% \text {. } \\
16 \% \text { of the patients } \\
\text { showed no improvement. }\end{array}$ & $\begin{array}{l}\text { Positive } \\
\text { short-term } \\
\text { and long- } \\
\text { term relief. }\end{array}$ \\
\hline $\begin{array}{l}\text { Manchikanti } \\
\text { et al (105) } \\
\text { Retrospective } \\
\text { evaluation of } \\
225 \text { patients } \\
\text { with chronic } \\
\text { low back } \\
\text { pain. }\end{array}$ & $\begin{array}{l}\text { Chronic pain } \\
\text { patients who have } \\
\text { failed to respond } \\
\text { to conservative } \\
\text { management with } \\
\text { physical therapy, } \\
\text { chiropractic and } \\
\text { medical therapy. }\end{array}$ & $\begin{array}{l}\text { Group I: Blind lumbar epidural } \\
\text { steroid injections, } \\
\text { Group II: Caudal epidural steroid } \\
\text { injections under fluoroscopy. } \\
\text { Group III: Transforaminal } \\
\text { epidural corticosteroid } \\
\text { injections under fluoroscopic } \\
\text { visualization. }\end{array}$ & $\begin{array}{l}\text { Duration of pain relief } \\
\text { with each injection. } \\
\text { Outcome measures: } \\
\text { relief } \geq 50 \%\end{array}$ & $\begin{array}{l}\text { Cumulative significant } \\
\text { relief, was reported } \\
\text { following } 3 \text { procedures } \\
\text { for a mean of } 10.3 \\
\pm 0.96 \text { weeks in patients } \\
\text { receiving caudal } \\
\text { epidurals, in contrast } \\
\text { to } 6.7 \pm 0.37 \text { weeks in } \\
\text { patients receiving blind } \\
\text { lumbar epidural steroid } \\
\text { injections. }\end{array}$ & $\begin{array}{l}\text { Positive } \\
\text { short-term } \\
\text { and long- } \\
\text { term relief. }\end{array}$ \\
\hline
\end{tabular}


Table 5. Characteristics and results of non-randomized studies of caudal epidural injections (Continued)

\begin{tabular}{|c|c|c|c|c|c|}
\hline $\begin{array}{l}\text { Study/ } \\
\text { Methods }\end{array}$ & Participants & Interventions & Outcomes & Results & $\begin{array}{l}\text { Outcomes/ } \\
\text { Conclusion }\end{array}$ \\
\hline $\begin{array}{l}\text { Goebert et al } \\
\text { (106) } \\
\text { Retrospective } \\
\text { evaluation of } \\
113 \text { patients. }\end{array}$ & $\begin{array}{l}113 \text { patients at a } \\
\text { tertiary care center } \\
\text { receiving } 120 \\
\text { injections. } 94 \text { were } \\
\text { caudal epidural } \\
\text { injections } \\
\text { There were no } \\
\text { objective signs present } \\
\text { in the patients. }\end{array}$ & $\begin{array}{l}\text { Epidural injections of } 30 \mathrm{~mL} \text { of } \\
1 \% \text { procaine combined with } 125 \\
\text { mg of hydrocortisone acetate } \\
\text { usually for } 3 \text { consecutive or } \\
\text { alternate days. }\end{array}$ & $\begin{array}{l}\text { Timing: } 3 \text { months } \\
\text { Pain relief: } \\
\text { Good result } 60 \% \text { relief for } \\
3 \text { months or longer } \\
\text { Failures: } 40 \% \text { to } 60 \% \\
\text { relief } \\
\text { Poor results: return } \\
\text { of pain in less than } 3 \\
\text { months or less than } 40 \% \\
\text { of relief. }\end{array}$ & $\begin{array}{l}\text { Overall good results in } \\
72 \% \text { of the patients with } \\
\text { poor results in } 17 \% \text {. }\end{array}$ & $\begin{array}{l}\text { Positive } \\
\text { short-term } \\
\text { and long- } \\
\text { term relief. }\end{array}$ \\
\hline $\begin{array}{l}\text { Ciocon et al } \\
\text { (107) } \\
\text { Evaluation } \\
\text { of elderly } \\
\text { patients }\end{array}$ & $\begin{array}{l}30 \text { patients with } \\
\text { various degrees of } \\
\text { degenerative lumbar } \\
\text { canal stenosis treated } \\
\text { with caudal epidural } \\
\text { steroid injections. } \\
\text { Mean age: } 76 \pm 6.7 \text { yrs }\end{array}$ & $\begin{array}{l}\text { A total of } 3 \text { caudal epidural } \\
\text { steroid injections of } 0.5 \% \\
\text { lidocaine with } 80 \mathrm{mg} \\
\text { of methylprednisolone } \\
\text { administered at weekly intervals }\end{array}$ & $\begin{array}{l}\text { Timing: initial and at 2- } \\
\text { month intervals up to } 10 \\
\text { months. } \\
\text { Outcome measures: } \\
\text { the Roland 5-point pain } \\
\text { rating scale. } \\
\text { Pain reduction and } \\
\text { walking capability. }\end{array}$ & $\begin{array}{l}\text { The results showed } \\
\text { significant pain reduction } \\
\text { for up to } 10 \text { months, with } \\
\text { satisfactory relief in } 90 \% \\
\text { of the patients. }\end{array}$ & $\begin{array}{l}\text { Positive } \\
\text { short-term } \\
\text { and long- } \\
\text { term relief. }\end{array}$ \\
\hline
\end{tabular}

and multiple other observational trials (132-161).

Of the 16 studies, 8 studies were excluded and only 8 met inclusion criteria. One study (112) was excluded as they studied effects of subarachnoid and epidural midazolam. Two studies $(118,119)$ studied diabetic polyneuropathy and intractable post herpetic neuralgia. One study (123) evaluated only inpatients, whereas 3 evaluations $(113,114,120)$ failed to evaluate long-term relief, and finally, one study (121) was not included due to lack of data for review. Table 6 illustrates various characteristics and results of published randomized or double blind trials meeting inclusion criteria. Of the 8 non-randomized prospective trials, only 3 trials (124-126) met criteria for inclusion, whereas the remaining 5 studies (127-131) were eliminated due to multiple issues.

Of the 8 randomized trials included in evaluation, 6 were positive for shortterm relief $(108,111,115-117,122)$, whereas only 3 were positive for longterm relief $(111,117,122)$. Numerous non-randomized trials, both prospective and retrospective, reported good results in $18 \%$ to $90 \%$ of patients receiving cervical or lumbar interlaminar epidural steroid injections, however, without specific follow-up period. Among the 3 prospective trials included for evaluation (124$126)$, only one was positive (125), one was indeterminate (124), and one was negative (126).

Of the 2 randomized trials, which were positive, Dilke et al (111) studied low back pain and sciatica, whereas Catanegra (117) studied chronic cervical radicular pain. Cuckler et al (110) also included post lumbar laminectomy syndrome patients with overall negative results. Due to a multitude of randomized trials and availability of double blind or randomized, and non-randomized prospective trials in managing lumbar radicular pain, evidence from retrospective trials was not included. However, due to only one randomized trial (117) and one prospective study (122), in managing cervical radicular pain, multiple retrospective trials (132144) were included for review. Retrospective reports were also considered in managing chronic low back pain with or without radiculopathy (145-161).

Some studies evaluated the effectiveness of cervical epidural steroid injections in patients not only with cervical radicular pain, but also other cervical pain problems $(134,137,140,142)$. One study (138) studied patients with cervical radiculopathy. All these retrospective studies show that there is probable benefit in a significant number of patients in short-term, however the benefits appear to be limited in long-term. The results for chronic low back pain also showed positive results in short-term and negative results in long-term in chronic low back pain.

\section{Transforaminal Epidural Injections}

Multiple reports evaluating the effectiveness of transforaminal epidural injections included 7 randomized trials (120, 162-167); 8 prospective evaluations (124,
168-174); one prospective evaluation of change in size and pattern of disc herniation (175); and multiple retrospective reports $(105,176-187)$.

Among the 7 randomized controlled trials, only 3 trials $(120,162,164)$ met criteria for inclusion. The trial by Kolsi et al (166) was not included since the measurements were only of short-term duration. Devulder et al (165) evaluated the effectiveness of transforaminal epidurals in post laminectomy syndrome. Karppinen et al $(163,164)$ used two publications to report the results of one trial. Buttermann (167) presented preliminary results at a scientific meeting in 1999 without subsequent publication. Details of the randomized trials examining the effectiveness of transforaminal epidural steroid injections in the management of spinal pain are illustrated in Table 7. All 3 studies showed effectiveness of transforaminal epidural steroids in managing nerve root pain. One study (164) showed ineffectiveness of transforaminal epidurals for disc extrusions.

Among the prospective evaluations, 3 investigations, those of Vad et al (169), Lutz et al (168), and Bush and Hillier (124) met inclusion criteria. Others were excluded because some were performed under CT, long-term results were not evaluated in some, and in others, multiple injections were performed in a short period of time. As shown in Table 8, all 3 prospective trials $(124,168,169)$ were positive for short-term and long-term relief. Among the retrospective evaluations, 4 studies by Weiner and Fraser 
Table 6. Characteristics of published randomized trials of interlaminar epidural injections

\begin{tabular}{|c|c|c|c|c|c|}
\hline $\begin{array}{l}\text { Study/ } \\
\text { Methods }\end{array}$ & Participants & Interventions & Outcomes & Results & $\begin{array}{l}\text { Outcomes/ } \\
\text { Conclusion }\end{array}$ \\
\hline $\begin{array}{l}\text { Carette et al } \\
(108) \\
\text { Randomized } \\
\text { double blind } \\
\text { trial }\end{array}$ & $\begin{array}{l}158 \text { patients with sciatica due to } \\
\text { a herniated nucleus pulposus. } \\
78 \text { patients in the treatment } \\
\text { group. } \\
80 \text { patients in the placebo } \\
\text { group. } \\
50 \% \text { of the patients had } L 4 / 5 \\
\text { disc herniation and } 46 \% \text { of } \\
\text { the patients had } L_{5} / \mathrm{S}_{1} \text { disc } \\
\text { herniation. }\end{array}$ & $\begin{array}{l}\text { Experimental group: } \\
\text { methylprednisolone } \\
\text { acetate (8o mg and } 8 \\
\mathrm{~mL} \text { of isotonic saline) } \\
\text { Control group: isotonic } \\
\text { saline } 1 \mathrm{~mL} \\
\text { Frequency: } 3 \text { epidural } \\
\text { injections } 3 \text { weeks } \\
\text { apart }\end{array}$ & $\begin{array}{l}\text { Timing: } 6 \text { weeks, } 3 \\
\text { months, } 12 \text { months } \\
\text { Outcome } \\
\text { measures: } \\
\text { Need for surgery } \\
\text { Oswestry Disability } \\
\text { scores }\end{array}$ & $\begin{array}{l}\text { After } 6 \text { weeks, a significant } \\
\text { difference was seen with } \\
\text { improvement in leg pain in the } \\
\text { methylprednisolone group. } \\
\text { After } 3 \text { months, there were no } \\
\text { significant differences between } \\
\text { groups. } \\
\text { At } 12 \text { months, the cumulative } \\
\text { probability of back surgery was } \\
\text { equal in both groups. }\end{array}$ & $\begin{array}{l}\text { Positive } \\
\text { short-term } \\
\text { Negative } \\
\text { long-term } \\
\text { relief }\end{array}$ \\
\hline $\begin{array}{l}\text { Snoek et al } \\
(109) \\
\text { Randomized } \\
\text { trial }\end{array}$ & $\begin{array}{l}51 \text { patients with lumbar root } \\
\text { compression documented } \\
\text { by neurological deficit and a } \\
\text { concordant abnormality noted } \\
\text { on myelography. } \\
27 \text { patients in experimental } \\
\text { group } \\
24 \text { patients in control group }\end{array}$ & $\begin{array}{l}\text { Experimental } \\
\text { group: } 80 \mathrm{mg} \text { of } \\
\text { methylprednisolone } \\
(2 \mathrm{~mL}) \\
\text { Control group: } 2 \mathrm{~mL} \text { of } \\
\text { normal saline } \\
\text { Frequency: single } \\
\text { injection }\end{array}$ & $\begin{array}{l}\text { Timing: } 3 \text { days and } \\
\text { an average of } 14 \\
\text { months } \\
\text { Outcome } \\
\text { measures: } \\
\text { Pain, sciatic nerve } \\
\text { stretch tolerance, } \\
\text { subjective } \\
\text { improvement, } \\
\text { surgical treatment. }\end{array}$ & $\begin{array}{l}\text { No statistically significant } \\
\text { differences were noted in } \\
\text { either group with regards to } \\
\text { low back pain, sciatic nerve } \\
\text { stretch tolerance, subjective } \\
\text { improvement, and surgical } \\
\text { treatment. }\end{array}$ & $\begin{array}{l}\text { Negative } \\
\text { short-term } \\
\text { and long- } \\
\text { term relief }\end{array}$ \\
\hline $\begin{array}{l}\text { Cuckler et al } \\
(110) \\
\text { Randomized } \\
\text { double blind } \\
\text { trial }\end{array}$ & $\begin{array}{l}73 \text { patients with back pain } \\
\text { due to either acute herniated } \\
\text { nucleus pulposus or spinal } \\
\text { stenosis. } \\
\text { Duration: greater than } 6 \text { months. } \\
\text { Experimental group }=42 \\
\text { patients, control group }=31 \\
\text { patients }\end{array}$ & $\begin{array}{l}\text { Experimental group: } \\
80 \mathrm{mg}(2 \mathrm{~mL}) \text { of } \\
\text { methylprednisolone }+ \\
5 \mathrm{~mL} \text { of procaine } 1 \% \\
\text { Control group: } 2 \\
\mathrm{~mL} \text { saline }+5 \mathrm{~mL} \text { of } \\
\text { procaine } 1 \%\end{array}$ & $\begin{array}{l}\text { Timing: } 24 \text { hours } \\
\text { and an average of } \\
20 \text { months } \\
\text { Outcome } \\
\text { measures: } \\
\text { subjective } \\
\text { improvement. } \\
\text { Need for surgery. }\end{array}$ & $\begin{array}{l}\text { There was no significant short- } \\
\text { term or long-term improvement } \\
\text { among both groups. }\end{array}$ & $\begin{array}{l}\text { Negative } \\
\text { short-term } \\
\text { and long- } \\
\text { term relief }\end{array}$ \\
\hline $\begin{array}{l}\text { Dilke et al (111) } \\
\text { Randomized } \\
\text { trial }\end{array}$ & $\begin{array}{l}100 \text { patients with low back pain } \\
\text { and sciatica of } 1 \text { week to more } \\
\text { than } 2 \text { yrs. } \\
51 \text { patients in experimental } \\
\text { group } \\
48 \text { patients in control group }\end{array}$ & $\begin{array}{l}\text { Experimental } \\
\text { group: } 10 \mathrm{~mL} \text { of } \\
\text { saline }+80 \mathrm{mg} \text { of } \\
\text { methylprednisolone } \\
\text { Control group: } 1 \mathrm{~mL} \text { of } \\
\text { saline } \\
\text { Frequency: up to } 2 \\
\text { injections separated } \\
\text { by } 1 \text { week } \\
\text { All patients received } \\
\text { physical therapy with } \\
\text { hydrotherapy and } \\
\text { exercise }\end{array}$ & $\begin{array}{l}\text { Timing: } 2 \text { weeks } \\
\text { and } 3 \text { months } \\
\text { Outcome } \\
\text { measures: time of } \\
\text { bedrest, days of } \\
\text { hospitalization, } \\
\text { pain relief, } \\
\text { consumption of } \\
\text { analgesics and } \\
\text { resumption of } \\
\text { work } 3 \text { months } \\
\text { later }\end{array}$ & $\begin{array}{l}60 \% \text { of the patients in the } \\
\text { treatment group and } 31 \% \text { of the } \\
\text { patients in the control group } \\
\text { improved immediately after the } \\
\text { injections. } \\
\text { A greater proportion of actively } \\
\text { treated patients had no pain at } \\
3 \text { months, took no analgesics, } \\
\text { resumed work and fewer of } \\
\text { them underwent subsequent } \\
\text { surgery or other non-surgical } \\
\text { treatment. }\end{array}$ & $\begin{array}{l}\text { Positive } \\
\text { short-term } \\
\text { and long- } \\
\text { term relief }\end{array}$ \\
\hline $\begin{array}{l}\text { Ridley et al } \\
\text { (115) } \\
\text { Randomized } \\
\text { trial }\end{array}$ & $\begin{array}{l}35 \text { patients with low back pain } \\
\text { and sciatica of mean duration } \\
\text { approximately } 8 \text { months } \\
19 \text { patients in experimental } \\
\text { group } \\
16 \text { patients in control group }\end{array}$ & $\begin{array}{l}\text { Experimental } \\
\text { group: } 10 \mathrm{~mL} \text { of } \\
\text { saline }+80 \mathrm{mg} \text { of } \\
\text { methylprednisolone } \\
(\mathrm{n}=19) \\
\text { Control group: saline } \\
2 \mathrm{~mL}, \text { interspinous } \\
\text { ligament }(\mathrm{n}=16)\end{array}$ & $\begin{array}{l}\text { Timing: } 1 \text { weeks, } 2 \\
\text { weeks, } 3 \text { months } \\
\text { and } 6 \text { months } \\
\text { Outcome } \\
\text { measures: } \\
\text { pain control } \\
\text { improvement in } \\
\text { straight leg raising }\end{array}$ & $\begin{array}{l}90 \% \text { of the patients in the } \\
\text { treated group compared to } 19 \% \\
\text { in the control group showed } \\
\text { improvement at } 1 \text { week, } 2 \\
\text { weeks and } 12 \text { weeks. } \\
\text { By } 24 \text { weeks, the relief } \\
\text { deteriorated to pre-treatment } \\
\text { levels }\end{array}$ & $\begin{array}{l}\text { Positive } \\
\text { short-term } \\
\text { relief } \\
\text { Negative } \\
\text { long-term } \\
\text { relief }\end{array}$ \\
\hline $\begin{array}{l}\text { Rogers et al } \\
(116) \\
\text { Randomized } \\
\text { single blind } \\
\text { sequential } \\
\text { analysis }\end{array}$ & $\begin{array}{l}30 \text { patients with low back pain } \\
15 \text { patients in experimental } \\
\text { group } \\
15 \text { patients in control group }\end{array}$ & $\begin{array}{l}\text { Experimental group: } \\
\text { local anesthetic }+ \\
\text { steroid } \\
\text { Control group: local } \\
\text { anesthetic alone }\end{array}$ & $\begin{array}{l}\text { Timing: } 1 \text { month } \\
\text { Outcome } \\
\text { measures: pain } \\
\text { relief } \\
\text { Nerve root tension } \\
\text { signs }\end{array}$ & $\begin{array}{l}\text { Lumbar epidural injection } \\
\text { of steroid together with } \\
\text { local anesthetic produced } \\
\text { significantly better results. } \\
\text { Long-term results were similar } \\
\text { for both. }\end{array}$ & $\begin{array}{l}\text { Positive } \\
\text { short-term } \\
\text { relief } \\
\text { Negative } \\
\text { long-term } \\
\text { relief }\end{array}$ \\
\hline $\begin{array}{l}\text { Catanegra et al } \\
\text { (117) } \\
\text { Randomized } \\
\text { trial with } \\
\text { cervical } \\
\text { interlaminar } \\
\text { epidural } \\
\text { steroid } \\
\text { injections }\end{array}$ & $\begin{array}{l}24 \text { patients with chronic cervical } \\
\text { radicular pain, however without } \\
\text { need of surgery, but suffering for } \\
\text { more than } 12 \text { months } \\
\text { i. } 14 \text { patients receiving local } \\
\text { anesthetic and steroid } \\
\text { ii. } 10 \text { patients receiving local } \\
\text { anesthetic, steroid + morphine } \\
\text { sulfate }\end{array}$ & $\begin{array}{l}\text { i. } 0.5 \% \text { lidocaine } \\
+ \text { triamcinolone } \\
\text { acetonide } \\
\text { ii. Local anesthetic } \\
+ \text { steroid }+2.5 \mathrm{mg} \text { of } \\
\text { morphine sulfate }\end{array}$ & $\begin{array}{l}\text { Timing: } 1 \text { month, } \\
3 \text { months, and } 12 \\
\text { months } \\
\text { Outcome } \\
\text { measures: pain } \\
\text { relief }\end{array}$ & $\begin{array}{l}\text { The success rate was } 79 \% \text { vs. } \\
80 \% \text { in group I and II. } \\
\text { Overall, initial success rate was } \\
96 \%, 75 \% \text { at } 1 \text { month, } 79 \% \text { at } \\
3 \text { months, } 6 \text { months, and } 12 \\
\text { months. }\end{array}$ & $\begin{array}{l}\text { Positive } \\
\text { short-term } \\
\text { and long- } \\
\text { term relief }\end{array}$ \\
\hline
\end{tabular}


Table 6. Characteristics of published randomized trials of interlaminar epidural injections (Continued)

\begin{tabular}{|c|c|c|c|c|c|}
\hline $\begin{array}{l}\text { Study/ } \\
\text { Methods }\end{array}$ & Participants & Interventions & Outcomes & Results & $\begin{array}{l}\text { Outcomes/ } \\
\text { Conclusion }\end{array}$ \\
\hline $\begin{array}{l}\text { Stav et al (122) } \\
\text { Randomized } \\
\text { trial of cervical } \\
\text { epidural } \\
\text { steroid } \\
\text { injections }\end{array}$ & $\begin{array}{l}52 \text { patients with chronic, } \\
\text { resistant cervical brachialgia } \\
25 \text { patients in experimental } \\
\text { group } \\
17 \text { patients in control group }\end{array}$ & $\begin{array}{l}\text { Experimental group: } \\
\text { cervical epidural } \\
\text { steroid and lidocaine } \\
\text { injections } \\
\text { Control group: } \\
\text { steroid and lidocaine } \\
\text { injections into the } \\
\text { posterior neck } \\
\text { muscles } \\
\text { Frequency: } 1 \text { to } 3 \\
\text { injections were } \\
\text { administered at } 2 \\
\text { weeks intervals, } \\
\text { based on the clinical } \\
\text { response } \\
\text { All patients continued } \\
\text { pre-study treatment } \\
\text { with drugs and } \\
\text { physiotherapy }\end{array}$ & $\begin{array}{l}\text { Timing: } 1 \text { week and } \\
1 \text { year } \\
\text { Outcome } \\
\text { measures: pain } \\
\text { relief, change } \\
\text { in deep tendon } \\
\text { reflexes or sensory } \\
\text { loss, change in } \\
\text { range of motion } \\
\text { Reduction of daily } \\
\text { dose of analgesics } \\
\text { Return to work }\end{array}$ & $\begin{array}{l}\text { After } 1 \text { week, } 76 \% \text { of the } \\
\text { patients in cervical epidural } \\
\text { group compared to } 36 \% \text { of the } \\
\text { patients in the neck injection } \\
\text { group showed improvement. } \\
\text { At } 1 \text { year, } 68 \% \text { of the cervical } \\
\text { epidural group continued to } \\
\text { have relief compared to } 12 \% \text { of } \\
\text { the control group. }\end{array}$ & $\begin{array}{l}\text { Positive } \\
\text { short-term } \\
\text { and long- } \\
\text { term relief }\end{array}$ \\
\hline
\end{tabular}

Table 7. Details of randomized trials studying the effectiveness of transforaminal epidural steroid injections for low back pain

\begin{tabular}{|c|c|c|c|c|c|}
\hline $\begin{array}{l}\text { Study/ } \\
\text { Methods }\end{array}$ & Participants & Interventions & Outcomes & Results & $\begin{array}{l}\text { Outcomes } \\
\text { /Conclusion }\end{array}$ \\
\hline $\begin{array}{l}\text { Riew et al (162) } \\
\text { Randomized } \\
\text { double blind } \\
\text { trial }\end{array}$ & $\begin{array}{l}55 \text { patients with lumbar } \\
\text { disc herniations or spinal } \\
\text { stenosis referred for surgical } \\
\text { evaluation. } \\
\text { All subjects had clinical } \\
\text { indications for surgery, and } \\
\text { radiographic confirmation of } \\
\text { nerve root compression. } \\
\text { All patients had failed a } \\
\text { minimum of } 6 \text { weeks of } \\
\text { conservative care or had } \\
\text { unrelenting pain. } \\
28 \text { patients in experimental } \\
\text { group (71\%) } \\
27 \text { patients in control group } \\
\text { (33\%) }\end{array}$ & $\begin{array}{l}\text { Experimental group: } \\
\text { transforaminal nerve root or } \\
\text { epidural steroid injection with } \\
1 \mathrm{~mL} \text { of } 0.25 \% \text { bupivacaine } \\
\text { and } 6 \mathrm{mg} \text { of betamethasone } \\
\text { Control group: } 1 \mathrm{~mL} \text { of } 0.25 \% \\
\text { bupivacaine. } \\
\text { The patient was allowed to } \\
\text { choose to receive as many as } \\
4 \text { injections at any time during } \\
\text { the follow-up. }\end{array}$ & $\begin{array}{l}\text { Timing: } 1 \text { year } \\
\text { Outcome measures: } \\
\text { Injections were } \\
\text { considered to have } \\
\text { failed if the patient } \\
\text { opted for operative } \\
\text { treatment. } \\
\text { Multiple injection } \\
\text { therapy was not } \\
\text { considered as } \\
\text { failure. } \\
\text { North American } \\
\text { Spine Society } \\
\text { questionnaire. }\end{array}$ & $\begin{array}{l}\text { Of the } 28 \text { patients } \\
\text { in the experimental } \\
\text { group with } \\
\text { bupivacaine and } \\
\text { betamethasone, } 20 \\
\text { decided not to have } \\
\text { the operation. } \\
\text { Of the } 27 \text { patients } \\
\text { in the control group } \\
\text { receiving bupivacaine } \\
\text { alone, } 9 \text { elected } \\
\text { not to have the } \\
\text { operation. They had } \\
\text { highly significant pain } \\
\text { relief and functional } \\
\text { improvement. }\end{array}$ & $\begin{array}{l}\text { Positive } \\
\text { short-term } \\
\text { and long-term } \\
\text { relief. }\end{array}$ \\
\hline $\begin{array}{l}\text { Kraemer et al } \\
(120) \\
\text { Randomized } \\
\text { double blind } \\
\text { study }\end{array}$ & $\begin{array}{l}49 \text { patients with lumbar } \\
\text { radicular symptoms with } 24 \\
\text { patients in the steroid group } \\
\text { and } 25 \text { patients in the normal } \\
\text { saline group. }\end{array}$ & $\begin{array}{l}\text { Experimental group: } \\
\text { transforaminal epidural with } \\
\text { local anesthetic and } 10 \mathrm{mg} \text { of } \\
\text { triamcinolone. } \\
\text { Control group: local } \\
\text { anesthetic only. } \\
\text { Normal saline group received } \\
\text { IM steroid injections to avoid } \\
\text { the systemic steroid effect. }\end{array}$ & $\begin{array}{l}\text { Timing: not } \\
\text { mentioned } \\
\text { Outcome measures: } \\
\text { Pain relief }\end{array}$ & $\begin{array}{l}\text { Single-short epidural } \\
\text { perineural injection } \\
\text { was effective it the } \\
\text { treatment of lumbar } \\
\text { radicular pain. }\end{array}$ & $\begin{array}{l}\text { Positive } \\
\text { short-term } \\
\text { and long-term } \\
\text { relief. }\end{array}$ \\
\hline $\begin{array}{l}\text { Karppinen et al } \\
(163,164) \\
\text { Randomized } \\
\text { double blind } \\
\text { trial }\end{array}$ & $\begin{array}{l}160 \text { consecutive, eligible } \\
\text { patients with sciatica with } \\
\text { unilateral symptoms of } 1 \text { to } 6 \\
\text { months duration. } \\
\text { None of the patients have } \\
\text { undergone surgery. }\end{array}$ & $\begin{array}{l}\text { Experimental group: } \\
\text { local anesthetic and } \\
\text { methylprednisolone } \\
\text { Control group: } \\
\text { normal saline }\end{array}$ & $\begin{array}{l}\text { Timing: } 2 \text { weeks, } 3 \\
\text { months, } 6 \text { months } \\
\text { Outcome measures: } \\
\text { Pain relief, sick } \\
\text { leaves, medical } \\
\text { costs, and future } \\
\text { surgery } \\
\text { Nottingham Health } \\
\text { Profile }\end{array}$ & $\begin{array}{l}\text { In the case of } \\
\text { contained herniations, } \\
\text { the steroid injection } \\
\text { produced significant } \\
\text { treatment effects } \\
\text { and short-term in } \\
\text { leg pain, straight leg } \\
\text { raising, disability and } \\
\text { in Nottingham Health } \\
\text { Profile, emotional } \\
\text { reactions and cost } \\
\text { effectiveness. }\end{array}$ & $\begin{array}{l}\text { Positive } \\
\text { short-term } \\
\text { and long-term } \\
\text { relief. }\end{array}$ \\
\hline
\end{tabular}


Table 8. Details and results of non-randomized trials of transforaminal epidural injections

\begin{tabular}{|c|c|c|c|c|c|}
\hline Study/Methods & Participants & Interventions & Outcomes & Results & $\begin{array}{l}\text { Outcomes/ } \\
\text { Conclusion }\end{array}$ \\
\hline $\begin{array}{l}\text { Vad et al (169) } \\
\text { A prospective } \\
\text { study randomized } \\
\text { by patient choice } \\
\text { from the private } \\
\text { practice of a single } \\
\text { physician. }\end{array}$ & $\begin{array}{l}\text { Patients with leg pain, old- } \\
\text { er than } 18 \text { years, had been } \\
\text { symptomatic longer than } \\
6 \text { weeks, had undergone } \\
\text { a lumbar spine magnetic } \\
\text { resonance imaging scan } \\
\text { documenting herniated } \\
\text { nucleus pulposus or mani- } \\
\text { fested clinical signs such } \\
\text { as radicular pain and sen- } \\
\text { sory or fixed motor defi- } \\
\text { cits consistent with lum- } \\
\text { bar radiculopathy. }\end{array}$ & $\begin{array}{l}\text { Experimental group: transforam- } \\
\text { inal epidural steroid injection. } \\
1.5 \mathrm{~mL} \text { each of betamethasone } \\
\text { acetate, } 9 \mathrm{mg} \text { and } 2 \% \text { preserva- } \\
\text { tive-free Xylocaine per level. } \\
\text { Control group: trigger point in- } \\
\text { jections. } \\
\text { All patients received a self-di- } \\
\text { rected home lumbar stabiliza- } \\
\text { tion program consisting of four } \\
\text { simple exercises emphasizing } \\
\text { hip and hamstring flexibility and } \\
\text { abdominal and lumbar paraspi- } \\
\text { nal strengthening. }\end{array}$ & $\begin{array}{l}\text { Timing: } 3 \text { weeks, } 6 \\
\text { weeks, } 3 \text { months, } \\
6 \text { months, and } 12 \\
\text { months. } \\
\text { Outcome mea- } \\
\text { sures: } \\
\text { Roland-Morris } \\
\text { score, visual nu- } \\
\text { meric score, finger- } \\
\text { to-floor distance, } \\
\text { patient satisfaction } \\
\text { score. }\end{array}$ & $\begin{array}{l}\text { Fluoroscopically guided } \\
\text { transforaminal epidural } \\
\text { steroid injections yielded } \\
\text { better results compared } \\
\text { to saline trigger point in- } \\
\text { jections. } \\
\text { The group receiving trans- } \\
\text { foraminal epidural steroid } \\
\text { injections had a success } \\
\text { rate of } 84 \% \text {, as compared } \\
\text { with the } 48 \% \text { for the group } \\
\text { receiving trigger point in- } \\
\text { jections. }\end{array}$ & $\begin{array}{l}\text { Positive } \\
\text { short-term } \\
\text { and long- } \\
\text { term relief }\end{array}$ \\
\hline $\begin{array}{l}\text { Lutz et al (168) } \\
\text { A prospective case } \\
\text { series. }\end{array}$ & $\begin{array}{l}69 \text { patients with lumbar } \\
\text { herniated nucleus pulpo- } \\
\text { sus and radiculopathy. } 69 \\
\text { patients were recruited. } \\
\text { Every patient in the case } \\
\text { series had documented } \\
\text { magnetic resonance imag- } \\
\text { ing findings that showed } \\
\text { disc herniation with nerve } \\
\text { root compression. }\end{array}$ & $\begin{array}{l}\text { Transforaminal epidural steroid } \\
\text { injections with } 1.5 \mathrm{cc} \text { of } 2 \% \mathrm{Xy} \text { - } \\
\text { locaine and } 9 \mathrm{mg} \text { of betametha- } \\
\text { sone acetate. }\end{array}$ & $\begin{array}{l}\text { Timing: } 28 \text { to } 144 \\
\text { weeks } \\
\text { Outcome mea- } \\
\text { sures: At least } \\
\pm 50 \% \text { reduction in } \\
\text { pre-injection and } \\
\text { post-injection visu- } \\
\text { al numerical pain } \\
\text { scores. }\end{array}$ & $\begin{array}{l}\text { A successful outcome } \\
\text { was reported by } 52 \text { of the } \\
69 \text { patients }(75.4 \% \text { ) at } \\
\text { an average follow-up of } \\
80 \text { weeks (range } 28-144 \\
\text { weeks). }\end{array}$ & $\begin{array}{l}\text { Positive } \\
\text { short-term } \\
\text { and long- } \\
\text { term relief }\end{array}$ \\
\hline $\begin{array}{l}\text { Bush and Hillier } \\
\text { (124) } \\
\text { Prospective evalu- } \\
\text { ation of cervical } \\
\text { interlaminar and } \\
\text { transforaminal } \\
\text { epidural injections }\end{array}$ & $\begin{array}{l}68 \text { patients with neck } \\
\text { pain and cervical } \\
\text { radiculopathy. }\end{array}$ & $\begin{array}{l}\text { Following the first blind cervical } \\
\text { epidural injection, if a significant } \\
\text { improvement was not seen, a } \\
\text { repeat injection was performed } \\
\text { trans foraminally with fluorosco- } \\
\text { py guidance within } 1 \text { month. } \\
\text { A third injection was also per- } \\
\text { formed if needed in the same } \\
\text { manner as the second injection. }\end{array}$ & $\begin{array}{l}\text { Timing: } 1 \text { month to } \\
1 \text { year } \\
\text { Outcome mea- } \\
\text { sures: Pain relief }\end{array}$ & $\begin{array}{l}93 \% \text { of the patients were } \\
\text { reported to have good pain } \\
\text { relief lasting for } 7 \text { months. }\end{array}$ & $\begin{array}{l}\text { Positive } \\
\text { short-term } \\
\text { and long- } \\
\text { term relief }\end{array}$ \\
\hline $\begin{array}{l}\text { Manchikanti et al } \\
\text { (105) } \\
\text { Compared the } 3 \\
\text { routes of epidural } \\
\text { steroid injections } \\
\text { in the manage- } \\
\text { ment of low back } \\
\text { in retrospective } \\
\text { manner }\end{array}$ & $\begin{array}{l}225 \text { patients randomly de- } \\
\text { rived from a total sample } \\
\text { of } 624 \text { patients suffering } \\
\text { with low back pain from } \\
\text { a total of } 972 \text { patients re- } \\
\text { ferred for pain manage- } \\
\text { ment were evaluated. }\end{array}$ & $\begin{array}{l}\text { Group I: interlaminar epidurals } \\
\text { with a midline approach without } \\
\text { fluoroscopy. } \\
\text { Group II: caudal epidurals un- } \\
\text { der fluoroscopy. } \\
\text { Group III: transforaminal epidu- } \\
\text { ral steroid injections. }\end{array}$ & $\begin{array}{l}\text { Timing: } 1,3,6,12 \\
\text { months } \\
\text { Outcome mea- } \\
\text { sures: Pain relief }\end{array}$ & $\begin{array}{l}\text { Group III reported } \pm 50 \% \\
\text { relief per procedure of } \\
7.69 \pm 1.20 \text { weeks, which } \\
\text { was superior to blind inter- } \\
\text { laminar epidurals. }\end{array}$ & $\begin{array}{l}\text { Positive } \\
\text { short-term } \\
\text { and long- } \\
\text { term relief }\end{array}$ \\
\hline $\begin{array}{l}\text { Rosenberg et al } \\
(186) \\
\text { Retrospective } \\
\text { evaluation }\end{array}$ & $\begin{array}{l}92 \text { patients with radicu- } \\
\text { lopathic back pain due } \\
\text { to spinal stenosis, herni- } \\
\text { ated discs, spondylolis- } \\
\text { thesis, and degenerative } \\
\text { discs. }\end{array}$ & $\begin{array}{l}\text { Group I: Previous back surgery } \\
\text { (16\%) } \\
\text { Group II: Discogenic abnormali- } \\
\text { ties: herniations, bulges or de- } \\
\text { generation ( } 42 \%) \\
\text { Group III: spinal stenosis ( } 32 \%) \\
\text { Group IV: those without MRI } \\
(11 \%)\end{array}$ & $\begin{array}{l}\text { Timing: } 2,6 \text { and } \\
12 \text { months } \\
\text { Outcome mea- } \\
\text { sures: } \\
\text { Pain relief }\end{array}$ & $\begin{array}{l}\text { The pain scores for all pa- } \\
\text { tients improved signifi- } \\
\text { cantly at all three points. } \\
\text { Greater than } 50 \% \text { im- } \\
\text { provement after one year } \\
\text { was seen in } 23 \% \text { of Group } \\
\text { I; } 59 \% \text { in Group II; } 35 \% \\
\text { in Group III and } 67 \% \text { in } \\
\text { Group IV. }\end{array}$ & $\begin{array}{l}\text { Positive } \\
\text { short-term } \\
\text { and long- } \\
\text { term relief }\end{array}$ \\
\hline $\begin{array}{l}\text { Wang et al (187) } \\
\text { Retrospective } \\
\text { evaluation }\end{array}$ & $\begin{array}{l}69 \text { patients with lumbar } \\
\text { herniated discs }\end{array}$ & $\begin{array}{l}\text { All patients were treated with 1- } \\
6 \text { epidural steroid injections }\end{array}$ & $\begin{array}{l}\text { Timing: NA } \\
\text { Outcome mea- } \\
\text { sures: Pain relief } \\
\text { Avoidance of sur- } \\
\text { geon }\end{array}$ & $\begin{array}{l}77 \% \text { of patients had sig- } \\
\text { nificant improvement and } \\
\text { refused surgery }\end{array}$ & $\begin{array}{l}\text { Positive } \\
\text { short-term } \\
\text { and long- } \\
\text { term relief }\end{array}$ \\
\hline
\end{tabular}


(183), Rosenberg et al (186), Wang et al (187) and Manchikanti et al (105) met inclusion criteria. All retrospective evaluations showed positive short-term and long-term relief.

\section{Complications and Side Effects}

The most common and worrisome complications and side effects of caudal, interlaminar, and transforaminal epidural injections are of two types: those related to the needle placement and those related to drug administration. Complications include dural puncture, spinal cord trauma, infection, hematoma formation, abscess formation, subdural injection, intracranial injection, epidural lipomatosis, pneumothorax, nerve damage, headache, death, brain damage, increased intracranial pressure, intravascular injection, vascular injury, cerebral vascular or pulmonary embolus, and effects of steroids (188-239). No major complications or side effects were reported in the trials presented in the review.

\section{DISCUSSION}

This systematic review evaluated the effectiveness of epidural injections in patients with chronic spinal pain. The evidence was evaluated for 3 types of epidurals separately.

For the transforaminal epidural injections, three $(120,162,164)$ of the 7 randomized trials $(120,162-167)$, showed positive short-term and long-term effectiveness for lumbar nerve root pain. Three prospective evaluations $(124,168$, 169) showed positive short and long-term results. Four retrospective evaluations $(105,183,186,187)$ were included which showed positive results overall. Multiple randomized and non-randomized trials of transforaminal epidural injections provided strong evidence for short-term and long-term relief in managing lumbar nerve root pain. Their effectiveness in post lumbar laminectomy syndrome and disc extrusions is inconclusive. There is no published evidence of effectiveness of transforaminal epidural injections in chronic neck or chronic low back pain, post cervical or laminectomy syndrome, and cervical or thoracic radicular pain.

The combined overall evidence of caudal epidural steroid injections, based on randomized trials and nonrandomized trials (prospective and retrospective trials) is strong for short-term relief and moderate for long-term relief with two $(92,93)$ of three (92-94) randomized trials, and 4 of 4 non-randomized trials (102-104106) demonstrating positive results in radicular pain. However, the evidence for chronic low back pain and spinal stenosis appears to be limited as there are no randomized or double-blind trials evaluating this effect. Non-randomized trials (100, $101,105,107)$ all showed positive results in chronic low back pain after the facet joint pain was excluded $(100,101,105)$, and also in spinal stenosis (107).

For interlaminar epidural injections, of the 8 randomized trials included, 6 trials $(108,111,115-117,122)$ showed positive evidence for short-term relief, and 3 of $8(111,117,122)$ showed positive evidence for long-term relief. The overall effectiveness of interlaminar epidural steroid injections in managing chronic spinal pain is moderate for short-term relief and limited for long-term relief in managing lumbar radicular pain. However, there was no significant evidence based on randomized trials of effectiveness of interlaminar epidural steroids in managing cervical radicular pain. Further analysis combining one randomized trial, one prospective trial and multiple retrospective evaluations (132-144), demonstrated moderate evidence for short-term, and limited evidence for long-term relief. The limited evidence for management of chronic low back pain without radiculopathy was based on all the retrospective studies.

The first systematic review of effectiveness of epidural steroid injections was performed by Kepes and Duncalf in 1985 (59). They concluded that the rationale for epidural and systemic steroids was not proven. However, in 1986 Benzon (60), utilizing the same studies, concluded that mechanical causes of low back pain, especially those accompanied by signs of nerve root irritation, may respond to epidural steroid injections. The difference in the conclusion of Kepes and Duncalf (59) and Benzon (60) may have been due to the fact that Kepes and Duncalf (59) included studies on systemic steroids whereas Benzon (60) limited his analysis to studies on epidural steroid injections only.

The debate concerning epidural steroid injections is also illustrated by the recommendations of the Australian $\mathrm{Na}$ tional Health and Medical Research Council Advisory Committee on epidural steroid injections (57). In this report, Bogduk et al (57) extensively studied cau- dal, interlaminar, and transforaminal epidural injections, including all the literature available at the time, and concluded that the balance of the published evidence supports the therapeutic use of caudal epidurals. They also concluded that the results of lumbar interlaminar epidural steroids strongly refute the utility of epidural steroids in acute sciatica. Bogduk (61) updated his recommendations in 1999, recommending against epidural steroids by the lumbar route because effective treatment required too high a number for successful treatment, but supporting the potential usefulness of transforaminal steroids for disc prolapse. In 1995, Koes et al (62) reviewed 12 trials of lumbar and caudal epidural steroid injections and reported positive results from only six studies. However, review of their analysis showed that there were 5 studies for caudal epidural steroid injections and 7 studies for lumbar epidural steroid injections. Four of the five studies involving caudal epidural steroid injections were positive, whereas 5 of 7 studies were negative for lumbar epidural steroid injections. Koes et al (63) updated their review of epidural steroid injections for low back pain and sciatica, including three more studies with a total of 15 trials which met the inclusion criteria. In this study, they concluded that of the 15 trials, eight reported positive results of epidural steroid injections. Both reviews mostly reflected the quality of studies, rather than any meaningful conclusion.

Nelemans et al's (66) Cochrane review of injection therapy for subacute and chronic benign low back pain included 21 randomized trials. Of these, 9 were of epidural steroids. They failed to separate caudal from interlaminar epidural injections, but still concluded that convincing evidence is lacking regarding the effects of injection therapy on low back pain. Rozenberg et al (70), in a systematic review, identified 13 trials of epidural steroid therapy. They concluded that 5 trials demonstrated greater pain relief within the first month in the steroid group as compared to the control group. Eight trials found no measurable benefits. They noticed many obstacles for meaningful comparison of cross studies, which included differences in the patient populations, steroid used, volume injected, and number of injections. These authors were unable to determine whether epidural steroids are effective in common low 
back pain and sciatica based on their review. Rozenburg et al (70) concluded that 3 of the top 5 rated studies did not demonstrate significant benefit of the steroid over the non-steroid group. Hopayiank and Mugford (71) expressed frustration over the conflicting conclusions from two systematic reviews of epidural steroid injections for sciatica and asked which evidence should general practitioners heed? Multiple previous reviews have criticized the studies evaluating the effectiveness of epidural injections. Criticisms ranged from methodology, small size of the study populations, and other limitations, including long-term follow-up and outcome parameters. Many of these deficiencies were noted in our review also, in spite of the fact that we have included non-randomized trials.

With respect to complications and side effects, only transient minor complaints were reported in the trials presented in this review. However, potential complications also have been described. Spinal cord trauma and spinal cord or epidural hematoma formation are catastrophic complications. One of the suggestions has been to perform interventional procedures only in an awake patient and in the cervical spine by limiting the midline injection to be performed only at C7/T1 except in rare circumstances. However, it has also been reported that even an awake patient may not be able to detect spinal cord puncture (241). Thus, the recommendation to limit the midline injection only at $\mathrm{C} 7 / \mathrm{T} 1$ is based neither on consistent clinical nor anatomical evidence. Three cases of paraplegia were reported after lumbosacral nerve root block in post lumbar laminectomy patients (229). In each patient, paraplegia was reported suddenly. In each patient after injection of a steroid solution, post procedure magnetic resonance imaging (MRI) revealed spinal cord edema in the low thoracic region. The authors postulated that in these patients, the spinal needle penetrated or injured an abnormally low dominant radiculomedullary artery, a recognized anatomical variant. This vessel, also known as artery of Adamkiewicz, in $85 \%$ of individuals arises between T9 and L2, usually from the left, but in a minority of people, may arise from the lower lumbar spine and rarely even from as low as S1 (229). Others also have reported similar complications (234-236). Side effects related to the administration of steroids are gener- ally attributed either to the chemistry or to the pharmacology of the steroids. The major theoretical complications of corticosteroid administration include suppression of pituitary-adrenal access, hypercorticism, Cushing's syndrome, osteoporosis, avascular necrosis of bone, steroid myopathy, epidural lipomatosis, weight gain, fluid retention, and hyperglycemia. One study (228) showed no significant difference in patients undergoing various types of interventional techniques with or without steroids. Further, it has also been shown that the most commonly used steroids in the epidural steroids in the United States, methylprednisolone acetate, triamcinolone acetonide, and betamethasone acetate, and phosphate mixture have all been shown to be safe at epidural therapeutic doses in both clinical and experimental studies (242-250).

\section{Conclusion}

This systematic review, which included not only randomized trials, but also all available non-randomized trials, showed variable effectiveness of epidural injections. Strong evidence was provided for transforaminal epidural steroid injections in managing lumbar nerve root pain. Moderate evidence was provided for caudal epidural steroid injections in managing lumbar radicular pain. Evidence for other conditions was either limited or inconclusive.

\section{REFERENCES}

1. Hellsing A, Bryngelsson I. Predictors of musculoskeletal pain in men. A twentyyear follow-up from examination at enlistment. Spine 2000; 25:3080-3086.

2. Lawrence RC, Helmick CG, Arnett FC. Es timates of the prevalence of arthritis and selected musculoskeletal disorders in the United States. Arthritis Rheum 1998; 41: 778-799.

3. Bressler HB, Keyes WJ, Rochon PA et al. The prevalence of low back pain in the elderly. A systemic review of the literature. Spine 1999; 24:1813-1819.

4. Cassidy D, Carroll L, Cotê P: The Saskatchewan Health and Back Pain Survey. The prevalence of low back pain and related disability in Saskatchewan Adults. Spine 1998; 23:1860-1867.

5. Côté DC, Cassidy JD, Carroll L. The Saskatchewan Health and Back Pain Survey. The prevalence of neck pain and related disability in Saskatchewan adults. Spine 1998; 23:1689-1698.

6. Elliott AM, Smith BH, Hannaford PC et al. The course of chronic pain in the community: Results of a 4-year follow-up study. Pain 2002; 99:299-307.

7. van den Hoogen HJ, Koes BW, Deville W et

\section{Author Affiliation: \\ Mark V. Boswell, MD, PhD}

Chief Division of Pain Medicine

Department of Anesthesiology

Case Western Reserve University

School of Medicine and University

Hospitals of Cleveland

11100 Euclid Avenue

Cleveland, Ohio, 44106

E-mail: mark.boswell@uhhs.com

\section{Hans C. Hansen, MD}

Medical Director

The Pain Relief Centers, PA

3451 Greystone Place SW

Conover, North Carolina 28613

E-mail: hans@hippocrates.org

\section{Andrea M. Trescot, MD}

Medical Director

The Pain Center

1895 Kingsley Ave. Suite 903

Orange Park, Florida 32073

E-mail:amt57@aol.com

\section{Joshua A. Hirsch, MD}

Harvard School of Medicine

Department of Interventional Radiology

Massachusetts General Hospital

55 Blossom St. Gray 289

Boston, Massachusetts 02114

E-mail: jahirsch@partners.org

al. The prognosis of low back pain in general practice. Spine 1997; 22:1515-1521.

8. Croft PR, Papageorgiou AC, Thomas E et al. Short-term physical risk factors for new episodes of low back pain. Prospective evidence from the South Manchester Back Pain Study. Spine 1999; 24:15561561.

9. Carey TS, Garrett JM, Jackman A et al. Recurrence and care seeking after acute back pain. Results of a long-term followup study. Medical Care 1999; 37:157-164.

10. Miedema HS, Chorus AM, Wevers CW, et al. Chronicity of back problems during working life. Spine 1998; 23:20212029.

11. Thomas E, Silman AJ, Croft PR et al. Predicting who develops chronic low back pain in primary care. A prospective study. Brit Med J 1999; 318:1662-1667.

12. Wahlgren DR, Atkinson JH, Epping-Jordan JE et al. One-year follow up of first onset low back pain. Pain 1997; 73:213221.

13. Schiottz-Christensen B, Nielsen GL, Hansen VK et al. Long-term prognosis of acute low back pain in patients seen in general practice: A 1-year prospective follow-up 
study. Fam Pract 1999; 16:223-232.

14. Ferguson SA, Marras WS, Gupta P. Longitudinal quantitative measures of the natural course of low back pain recovery. Spine 2000; 25:1950-1956.

15. Vingård $\mathrm{E}$, Mortimer $\mathrm{M}$, Wiktorin $\mathrm{C}$ et al. Seeking care for low back pain in the general population: A two-year follow-up study: Results from the MUSIC-Norrtalje Study. Spine 2002; 27:2159-2165.

16. Hildingsson C, Toolanen G. Outcome after soft-tissue injury of the cervical spine: A prospective study of 93 car accident victims. Acta Orthop Scand 1990; 61:357359.

17. Hodgson S, Grundy M. Whiplash injuries: Their long-term prognosis and its relationship to compensation. Neuro Orthopedics 1989; 7:88-91.

18. Paul R, Haydon RC, Cheng $\mathrm{H}$ et al. Potential use of soxg gene therapy for intervertebral degenerative disc disease. Spine 2003; 28:755-763.

19. CDC. Prevalence of disabilities and associated health conditions among adults United States, 1999. MMWR 2001; 50:120125 .

20. Leigh JP, Markowitz S, Fahs M et al. Occupational injury and illness in the United States. Estimates of costs, morbidity, and mortality. Arch Intern Med 1997; 157: 1557-1568.

21. Freedman VA, Martin LG, Schoeni RF. Recent trends in disability and functioning among older adults in the united states. JAMA 2002; 288:3137-3146.

22. Wheeler AH, Murrey DB. Chronic lumbar spine and radicular pain: Pathophysiology and treatment. Curr Pain Headache Rep 2002; 6:97-105.

23. Antoniou J, Steffen T, Nelson F et al. The human lumbar intervertebral disc: Evidence for changes in the biosynthesis and denaturation of the extracellular matrix with growth, maturation, ageing, and degeneration. J Clin Invest 1996; 98:9961003.

24. Buckwalter JA. Aging and degeneration of the human intervertebral disc. Spine 1995; 20:1307-1314.

25. Guiot BH, Fessler RG. Molecular biology of degenerative disc disease. Neurosurgery 2000; 47:1034-1040.

26. Mixter WJ, Ayers JB. Herniation or rupture of the intervertebral disc into the spinal canal. N Engl J Med 1935; 213:385-395.

27. Mixter WJ, Barr JS. Rupture of the intervertebral disc with involvement of the spinal canal. N Eng J Med 1934; 211:210-215.

28. Luoma K, Riihimaki H, Luukkonen R et al. Low back pain in relation to lumbar disc degeneration. Spine 2000; 25: 487-492.

29. Paajanen H, Erkintalo M, Parkkola R et al. Age-dependent correlation of low back pain and lumbar disc regeneration. Arch Orthop Trauma Surg 1997; 116:106-107.

30. Salminen JJ, Erkintalo MO, Pentti J et al. Recurrent low back pain and early disc de- generation in the young. Spine 1999; 24: 1316-1321.

31. Olmarker K, Holm S, Rosenqvist AL et al. Experimental nerve root compression. Presentation of a model for acute, graded compression of the porcine cauda equina, with analysis of neural and vascular anatomy. Spine 1992; 16:61-69.

32. McCarron RF, Wimpee MW, Hudkins PG et al. The inflammatory effects of nucleus pulposus: A possible element in the pathogenesis of low back pain. Spine 1987; 12:760-764.

33. Olmarker K, Blomquist J, Stromberg J et al. Inflammatogenic properties of nucleus pulposus. Spine 1995; 20:665-669.

34. Saal JS, Franson RC, Dobrow R et al. High levels of inflammatory phospholipase A2 activity in lumbar disc herniations. Spine 1990; 15:674-678.

35. Chaoyang C, Cavanaugh JM, Ozaktay AC et al. Effects of phospholipase $A_{2}$ on lumbar nerve root structure and function. Spine 1997; 22:1057-1064.

36. Gertzbein SD. Degenerative disc disease of the lumbar spine: Immunological implications. Clin Orthop Rel Res 1977; 190:6871.

37. Marshall LL, Trethewie ER, Curtain CC. Chemical radiculitis: A clinical, physiological, and immunological study. Clin Orthop Rel Res 1977; 190:61-67.

38. Miyamoto H, Saura R, Doita M et al. The role of cyclooxygenase-2 in lumbar disc herniation. Spine 2002; 27:2477-2483.

39. Kang JD, Georgescu HI, McIntyre-Larkin $L$ et al. Herniated lumbar intervertebral discs spontaneously produce matrix metalloproteinases, nitric oxide, interleukin6 , and prostaglandin $\mathrm{E}_{2}$. Spine 1996; 21: 271-277.

40. Takahashi H, Suguro T, Okazim Y et al. Inflammatory cytokines in the herniated disc of the lumbar spine. Spine 1996; 21:218221.

41. Cavanaugh JM. Neural mechanisms of lumbar pain. Spine 1995; 20:1804-1809.

42. Weinstein JN. The role of neurogenic and non-neurogenic mediators as they relate to pain and the development of osteoarthritis. A clinical review. Spine 1992; 10: S356-S361.

43. Karppinen J, Korhonen T, Malmivaara A et al. Tumor necrosis factor- monoclonal antibody, infliximab, used to manage severe sciatica. Spine 2003; 28:751-754.

44. Igarashi T, Kikuchi S, Shubayev $\mathrm{V}$ et al. Volvo Award Winner in Basic Science Studies. Exogenous tumor necrosis facto-alpha mimics nucleus pulposus-induced neuropathology: Molecular, histologic, and behavioral comparisons in rats. Spine 2000; 25:2975-2980.

45. Crock HV. Isolated lumbar disc resorption as a cause of nerve root canal stenosis. Clin Orthop 1976; 115:109-115.

46. Olmarker K, Rydevik B, Holm S. Edema formation in spinal nerve roots induced by ex- perimental, graded compression: An experimental study on the pig cauda equina with special reference to differences in effects between rapid and slow onset of compression. Spine 1989; 14:569-573.

47. Law JD, Lehman RAW, Kirch WM. Reoperation after lumbar intervertebral disc surgery. J Neurosurg 1978; 48:259-263.

48. Fritsch EW, Heisel J, Rupp S. The failed back surgery syndrome. Reasons, intraoperative findings, and long-term results: $A$ report of 182 operative treatments. Spine 1996; 21:626-633.

49. Ross JS, Robertson JT, Frederickson RC et al. Association between peridural scar and recurrent radicular pain after lumbar discectomy: Magnetic resonance evaluation. Neurosurgery 1996; 38:855-863.

50. Nachemson AL. Failed back surgery syndrome is syndrome of failed back surgeons. Pain Clinic 1999; 11:271-284.

51. Spencer DL, Irwin GS, Miller JA. Anatomy and significance of fixation of the lumbosacral nerve roots in sciatica. Spine 1983; 8:672-679.

52. Amundsen $\mathrm{T}$, Weber $\mathrm{H}$, Nordal $\mathrm{H}$ et al. Lumbar spinal stenosis: Conservative or surgical management? Spine 2000; 25: 1424-1436.

53. Aota Y, Onari K, An HS et al. Dorsal root ganglia morphologic features in patients with herniation of the nucleus pulposus. Assessment using magnetic resonance myelography and clinical correlation. Spine 2001; 26:2125-2132.

54. Rydevik BL, Myers RR, Powel HC. Pressure increase in the dorsal root ganglion following mechanical compression: Closed compartment syndrome in nerve roots. Spine 1989; 14:574-576.

55. Weinstein J. Mechanism of spinal pain: The dorsal root ganglion and its role as a pain mediator of low-back pain. Spine 1986; 11:999-1001.

56. Manchikanti L, Staats P, Singh V et al. Evidence-based practice guidelines for interventional techniques in the management of chronic spinal pain. Pain Physician 2003; 6:3-80.

57. Bogduk N, Christophidis N, Cherry D et al. Epidural use of steroids in the management of back pain. Report of working party on epidural use of steroids in the management of back pain. National Health and Medical Research Council. Canberra, Commonwealth of Australia, 1994, pp 1-76.

58. Manchikanti L, Singh V, Kloth D et al. Interventional techniques in the management of chronic pain: Part 2.o. Pain Physician 2001; 4:24-98.

59. Kepes ER, Duncalf D. Treatment of back ache with spinal injections of local anesthetics, spinal and systemic steroids. Pain 1985; 22:33-47.

6o. Benzon HT. Epidural steroid injections for low back pain and lumbosacral radiculography. Pain 1986; 24:277. 
61. Bogduk N. Epidural steroids for low back pain and sciatica. Pain Digest 1999; 9: 226-7.

62. Koes BW, Scholten RJ, Mens JM et al. Efficacy of epidural steroid injections for low back pain and sciatica: A systematic review of randomized clinical trials. Pain 1995; 63:279-288.

63. Koes BW, Scholten R, Mens JM et al. Epidural steroid injections for low back pain and sciatica. An updated systematic review of randomized clinical trials. Pain $\mathrm{Di}$ gest 1999; 9:241-247.

64. Watts RW, Silagy CA. A meta-analysis on the efficacy of epidural corticosteroids in the treatment of sciatica. Anaesth Intens Care 1995; 23:564-569.

65. van Tulder MW, Koes BW, Bouter LM. Conservative treatment of acute and chronic nonspecific low back pain. A systematic review of randomized controlled trials of the most common interventions. Spine 1997; 22:2128-2156.

66. Nelemans PJ, deBie RA, deVet $\mathrm{HC}$ et al. Injection therapy for subacute and chronic benign low back pain. Spine 2001; 26:501515 .

67. Manchikanti L, Jasper J, Singh V. Letter to the editor. Spine 2001; 26:2641-2642.

68. McQuay HJ, Moore RA. Epidural corticosteroids for sciatica. An Evidence-Based Resource for Pain Relief. Oxford University Press, New York, 1998, pp 216-218.

69. Vroomen PC, de Krom MC, Slofstra PD et al. Conservative treatment of sciatica: A systematic reivew. J Spinal Disord 2000; 13:463-469.

70. Rozenberg S, Dubourg G, Khalifa P et al. Efficacy of epidural steroids in low back pain and sciatica: A critical appraisal by a French task force of randomized trials. Revue du Rhumatisme 1999; 66:79-85.

71. Hopayiank K, Mugford M. Conflicting conclusions from two systematic reviews of epidural steroid injections for sciatica: Which evidence should general practitioners heed? BrJ Gen Pract 1999; 49:57-60.

72. Bogduk N, Govind J (eds). Epidural steroids. In Medical Management of Acute Lumbar Radicular Pain. $1^{\text {st }}$ ed. University of Newcastle, Newcastle Bone and Joint Institute, Australia, 1999, pp 71-80

73. Bogduk N (ed). Steroid injections. In Medical Management of Acute Cervical Radicular Pain. $1^{\text {st }}$ ed. University of Newcastle, Newcastle Bone and Joint Institute, Australia, 1999. pp 85-90.

74. Bogduk N, McGuirk B (eds). Monotherapy. In Medical Management of Acute and Chronic Low Back Pain. Vol 13. Elsevier Science, Netherlands, 2002, pp 143-162.

75. van Tulder MW, Goossens M, Waddell G et al. Conservative treatment of chronic low back pain. In Neck and Back Pain. The Scientific Evidence of Causes, Diagnosis, and Treatment. Lippincott Williams \& Wilkins, Philadelphia, pp 271-304.

76. Fox AJ, Melzack R. Transcutaneous electrical stimulation to acupuncture. Compar- ison of treatment of low back pain. Pain 1976; 2:141-148.

77. Byrod G, Otani K, Brisby $\mathrm{H}$ et al. Methylprednisolone reduces the early vascular permeability increase in spinal nerve roots induced by epidural nucleus pulposus application. J Orthop Res 2000; 18:983-987.

78. Fowler RJ, Blackwell GJ. Anti-inflammatory steroid induced biosynthesis of a phospholipase $\mathrm{A}_{2}$ inhibitor which prevents prostaglandin generation. Nature 1979; 278:456-459.

79. Devor M, Govrin-Lippmann R, Raber P. Corticosteroids suppress ectopic neural discharges originating in experimental neuromas. Pain 1985; 22:127-137.

8o. Johansson A, Hao J, Sjolund B. Local corticosteroid application blocks transmission in normal nociceptor C-fibers. Acta Anaesthesiol Scand 1990; 34:335-338.

81. Olmarker K, Byrod G, Cornefjord M et al. Effects of methylprednisolone on nucleus pulposus-induced nerve root injury. Spine 1994; 19:1803-1808.

82. Hua SY, Chen YZ. Membrane receptor-mediated electrophysiological effects of glucocorticoid on mammalian neurons. Endocrinology 1989; 124:687-691.

83. Hayashi N, Weinstein JN, Meller ST et al. The effect of epidural injection of betamethasone or bupivacaine in a rat model of lumbar radiculopathy. Spine 1998; 23: 877-885.

84. Lee HM, Weinstein JN, Meller ST et al. The role of steroids and their effects on phospholipase $A_{2}$. An animal model of radiculopathy. Spine 1998; 23:1191-1196.

85. Minamide A, Tamaki T, Hashizume $\mathrm{H}$ et al. Effects of steroids and lipopolysaccharide on spontaneous resorption of herniated intervertebral discs. An experience study in the rabbit. Spine 1998; 23:870-876.

86. Kingery WS, Castellote JM, Maze M. Methylprednisolone prevents the development of autotomy and neuropathic edema in rats, but has no effect on nociceptive thresholds. Pain 1999; 80:555-566.

87. Johansson A, Bennett GJ. Effect of local methylprednisolone on pain in a nerve injury model. A pilot study. Reg Anesth 1997; 22:59-65.

88. Merskey H, Thompson EN. Nerve blocks and cognitive therapy: A beneficial failure. Pain Res Manage 2002; 7:175-176.

89. Li YM, Wingrove DE, Too HP et al. Local anesthetics inhibit substance $P$ binding and evoked increases in intracellular $\mathrm{Ca}^{2+}$. Anesthesiology 1995:82:166-173.

90. Fink BR, Cairns AM. Differential use-dependent (frequency-dependent) effects in single mammalian axons: Data and clinical considerations. Anesthesiology 1987; 67: 477-484.

91. Systems to rate the strength of scientific evidence. Evidence Report/Technology Assessment No. 47 University of North Carolina: Agency for Healthcare Research and Quality. AHRQ Publication No. 02Eo16; April 2002.
92. Breivik H, Hesla PE, Molnar I et al. Treatment of chronic low back pain and sciatica. Comparison of caudal epidural injections of bupivacaine and methylprednisolone with bupivacaine followed by saline. In Bonica JJ, Albe-Fesard D (eds). Advances in pain research and therapy. Vol. 1., Raven Press, New York, 1976, pp 927-932.

93. Bush K, Hillier S. A controlled study of caudal epidural injections of triamcinolone plus procaine for the management of intractable sciatica. Spine 1991; 16:572575 .

94. Mathews JA, Mills SB, Jenkins VM et al. Back pain and sciatica: Controlled trials of manipulation, traction, sclerosant and epidural injections. Brit J Rheumatol 1987; 26:416-423.

95. Beliveau P. A comparison between epidural anesthesia with and without corticosteroids in the treatment of sciatica. Rheum Phys Med 1971; 11:40-43.

96. Czarski Z. Leczenie rwy kulszowej wstrzykiwaniem hydrokortyzonu inowokainy do rozworu kryzowego. Przeglad Kekarski 1965; 21:511-513.

97. Helsa PE, Breivik H. Epidural analgesia and epidural steroid injection for treatment of chronic low back pain and sciatica. Tidsskr Nor Laegeforen 1979; 99:936939.

98. Revel M, Auleley GR, Alaoui S et al. Forceful epidural injections for the treatment of lumbosciatic pain with post-operative lumbar spinal fibrosis. Rev Rhum Engl Ed 1996; 63:270-277.

99. Meadeb J, Rozenberg S, Duquesnoy B et al. Forceful sacrococcygeal injections in the treatment of postdiscectomy sciatica. A controlled study versus glucocorticoid injections. Joint Bone Spine 2001; 68:4349.

100. Manchikanti L, Pampati V, Rivera JJ et al. Caudal epidural injections with Sarapin steroids in chronic low back pain. Pain Physician 2001; 4:322-335.

101. Manchikanti L., Singh V, Rivera J et al. Effectiveness of caudal epidural injections in discogram positive and negative chronic low back pain. Pain Physician 2002; 5 : 18-29.

102. Yates DW. A comparison of the types of epidural injection commonly used in the treatment of low back pain and sciatica. Rheum Rehab 1978; 17:181-186.

103. Waldman SD. The caudal epidural administration of steroids in combination with local anesthetics in the palliation of pain secondary to radiographically documented lumbar herniated disc: A prospective outcome study with 6-months follow-up. Pain Clinic 1998; 11:43-49.

104. Hauswirth R, Michot F. Caudal epidural injection in the treatment of low back pain. Ischweizerische Medizinische Wochenschrift 1982; 112:222-225.

105. Manchikanti L, Pakanati RR, Pampati V. Comparison of three routes of epidural steroid injections in low back pain. Pain 
Digest 1999; 9:277-285.

106. Goebert HW, Jallo SJ, Gardner WJ et al. Painful radiculopathy treated with epidural injections of procaine and hydrocortisone acetate: Results in 113 patients. Anesth Analg 1961; 140:130-134.

107. Ciocon JO, Galindo-Clocon D, Amaranath $L$ et al. Caudal epidural blocks for elderly patients with lumbar canal stenosis. J Am Geriatr Soc 1994; 42:593-596.

108. Carette S, Leclaire R, Marcoux S et al. Epidural corticosteroid injections for sciatica due to herniated nucleus pulposus. $N$ Engl J Med 1997; 336:1634-1640.

109. Snoek W, Weber H, Jorgensen B. Doubleblind evaluation of extradural methylprednisolone for herniated lumbar disc. Acta Orthop Scand 1977; 48:635-641.

110. Cuckler JM, Bernini PA, Wiesel SW et al. The use of epidural steroid in the treatment of radicular pain. J Bone Joint Surg $1985 ; 67: 63-66$

111. Dilke TF, Burry HC, Grahame R. Extradural corticosteroid injection in the management of lumbar nerve root compression. Br Med J 1973; 2:635-637.

112. Serrao JM, Marks RL, Morley SJ et al. Intrathecal midazolam for the treatment of chronic mechanical low back pain: A controlled comparison with epidural steroid in a pilot study. Pain 1992; 48:5-12.

113. Klenerman L, Greenwood R, Davenport $\mathrm{HT}$ et al. Lumbar epidural injections in the treatment of sciatica. Br J Rheumatol 1984; 23:35-38.

114. Rocco AG, Frank E, Kaul AF et al. Epidural steroids, epidural morphine and epidural steroids combined with morphine in the treatment of post-laminectomy syndrome. Pain 1989; 36:297-303.

115. Ridley MG, Kingsley GH, Gibson T et al. Outpatient lumbar epidural corticosteroid injection in the management of sciatica. BrJ Rheumatol 1988; 27:1003-1007.

116. Rogers P, Nash T, Schiller D et al. Epidural steroids for sciatica. Pain Clinic 1992; 5: 67-72.

117. Castagnera L, Maurette P, Pointillart V et al. Long-term results of cervical epidural steroid injection with and without morphine in chronic cervical radicular pain. Pain 1994; 58:239-243.

118. Hernandez R, Lopez F. Assessment of pain intensity in patients with diabetic polyneuropathy treated with peridural $2 \% \mathrm{li}$ docaine methylprednisolone acetate vs peridural $2 \%$ lidocaine. Anestesia en Mexico 1999; 11:65-69.

119. Kikuchi A, Kotani N, Sato T et al. Comparative therapeutic evaluation of intrathecal versus epidural methylprednisolone for long-term analgesia in patients with intractable postherpetic neuralgia. Reg Anesth Pain Med 1999; 24:287-293.

120. Kraemer J, Ludwig J, Bickert U et al. Lumbar epidural perineural injection: A new technique. Eur Spine J 1997; 6:357-361.

121. Helliwell M, Robertson JC, Ellia RM. Out- patient treatment of low back pain and sciatica by a single extradural corticosteroid injection. BrJ Clin Pract 1985; 39:228-31.

122. Stav A, Ovadia L, Sternberg A et al. Cervical epidural steroid injection for cervicobrachialgia. Acta Anaesthesiol Scand 1993; 37:562-566.

123. Buchner M, Zeifang F, Brocai DR et al. Epidural corticosteroid injection in the conservative management of sciatica. Clin Orth Rel Res 2000; 375:149-156.

124. Bush K, Hillier S. Outcome of cervical radiculopathy treated with periradicular/ epidural corticosteroid injections: A prospective study with independent clinical review. Eur Spine J 1996; 5:319-325.

125. Rull BM, Miralles M, Aure S. Therapeutic epidural infiltrations in the lumbar nerve roots. Revista de Ortopedia y Traumatologia 1996; 40:209-217.

126. Caglar S, Erdine S, Aldemir T. The results of the epidural steroid injections in patients with radiculopathies due to lumbar disc herniations. Fizik Tedavi Rehabilitasyon Dergisi 1995; 19:186-190.

127. Rivest C, Katz JN, Ferrante FM et al. Effects of epidural steroid injection on pain due to lumbar spinal stenosis or herniated discs: A prospective study. Arthritis Care Res 1998; 11:291-297.

128. Koning HM, Koning AJ, Bruinen TC et al. The period of pain relief following a successful epidural steroid injection for low back pain. Pain Clinic 2002; 13:331-338.

129. Fukusaki M, Kobayashi I, Hara T et al. Symptoms of spinal stenosis do not improve after epidural steroid injection. Clin J Pain 1998; 14:148-151.

130. Andersen KH, Mosdal C. Epidural application of corticosteroids in low-back pain and sciatica. Acta Neurochir 1987; 87:5253.

131. Warfield CA, Crews DA. Epidural steroid injection as a predictor of surgical outcome. Surg Gyn Obstet 1987; 164:457458.

132. Stav A, Ovadia L, Landau M et al. Epidural steroid injection in the treatment of lumbar and cervical pain syndromes. A preliminary retrospective comparison. Pain Clinic 1991; 4:95-112.

134. Shulman M. Treatment of neck pain with cervical epidural steroid injection. Reg Anesth 1986; 11:92-94.

135. Catchlove RFH, Braha R. The use of cervical epidural nerve blocks in the management of chronic head and neck pain. Can Anaesth Soc J 1984; 31:188-191.

136. Berman AT, Garbarinbo JL Jr., Fisher SM et al. The effects of epidural injection of local anesthetics and corticosteroids in patients with lumbosciatic pain. Clin Orthop 1984; 188:144-151.

137. Purkis IE. Cervical epidural steroids. Pain Clinic 1986; 1:3-7.

138. Rowlingson JC, Kirschenbaum LP. Epidural analgesic techniques in the management of cervical pain. Anesth Analg 1986; 65:
938-942.

139. Warfield CA, Biber MP, Crews DA et al. Epidural steroid injection as a treatment for cervical radiculitis. Clin J Pain 1988; 4:201204.

140. Cicala RS, Thoni K, Angel JJ. Long-term results of cervical epidural steroid injections. Clin J Pain 1989; 5:143-145.

141. Pawl RP, Anderson W, Shulman M. Effect of epidural steroids in the cervical and lumbar region on surgical intervention for discogenic spondylosis. Clin J Pain 1985; 1:181-185.

142. Ferrante FM, Wilson SP, lacobo C et al. Clinical classification as a predictor of therapeutic outcome after cervical epidural steroid injection. Spine 1993; 18:730736.

143. Klein RG, Vaccaro AR, Cwik J et al. Efficacy of cervical epidural steroids in the treatment of cervical spine disorders. Am J Anesthesiol 2000; 9:547-552.

144. Ozyalcin S, Yucel A, Erdine S. Epidural steroid injection in the treatment of cervical pain syndromes: A retrospective follow up study. Angri Dergisi 1996; 8:9-14.

145. Hickey RF. Outpatient epidural steroid injections for low back pain and lumbosacral radiculopathy. NZ Med J 1987; 100:54-59.

146. Heyse-Moore GH. A rational approach to the use of epidural medication in the treatment of sciatic pain. Acta Orthop Scand 1978; 49:366-370.

147. Harley C. Extradural corticosteroid infiltration. A follow-up study of 50 cases. Ann Phy Med 1966; 9:22-28.

148. Sharma S, Stedman R. Epidural steroids. A retrospective analysis of the efficacy of high and low dose therapy. Anesthesiology 1998; 3A:A1135.

149. Rosen CD, Kahanovitz N, Berstein R et al. $A$ retrospective analysis of the efficacy of epidural steroid injections. Clin Orthop 1988; 228:270-272.

150. Arnhoff FN, Triplett HB, Pokorney B. Follow-up status of patients treated with nerve blocks for low back pain. Anesthesiology 1977; 46:170-178.

151. Jamison RN, VadeBoncouer T, Ferrante FM. Low back pain patients unresponsive to an epidural steroid injection: Identifying predictive factors. Clin J Pain 1991; 7:311317.

152. Hopwood MB, Abram SE. Factors associated with failure of lumbar epidural steroids. Reg Anesth 1993; 18:238-243.

153. Reale C, Turkiewicz AM, Reale CA et al. Epidural steroids as a pharmacological approach. Clin Exp Rheumatol 2000; 18: S65-S66.

154. Bowman SJ, Wedderburn L, Whaley A et al. Outcome assessment after epidural corticosteroid injection for low back pain and sciatica. Spine 1993; 18:1345-1350.

155. Jurmand SH. Cortiotherapie peridurale des lombalgies et des sciatiques d'origine discale. Concours Medicale 1972; 94: 5061-5070. 
156. Ito R. The treatment of low back pain and sciatica with epidural corticosteroids injection and its pathophysiologic basis. J Jpn Orthop Assoc 1971; 45:769-777.

157. Brown FW. Management of discogenic pain using epidural and intrathecal steroids. Clin Orthop 1977; 129:72-78.

158. Warr AC, Wilkinson JA, Burn JM et al. Chronic lumbosciatica syndrome treated by epidural injection and manipulation. Practitioner 1977; 209:53-59.

159. Papagelopoulos PJ, Petrou HG, Triantafyllidis PG et al. Treatment of lumbosacral radicular pain with epidural steroid injections. Orthopedics 2001; 24:145-149.

16o. Silva J, Costa AO, Simoes MT et al. Management of radicular pain from lumbar herniated disc using betamethasone epidural injection. Revista Brasileira de Ortopedia 1999; 34:165-168.

161. Mangar D, Thomas PB. Epidural steroid injections in the treatment of cervical and lumbar pain syndromes. Reg Anesth 1991; $16: 246$.

162. Riew KD, Yin Y, Gilula L et al. The effect of nerve-root injections on the need for operative treatment of lumbar radicular pain. J Bone Joint Surg 2000; 82A: 1589-1593.

163. Karppinen J, Malmivaara A, Kurunlahti M et al. Periradicular infiltration for sciatica. Spine 2001; 26:1059-1067.

164. Karppinen J, Ohinmaa A, Malmivaara A et al. Cost effectiveness of periradicular infiltration for sciatica. Spine 2001; 26:25872595.

165. Devulder J, Deene P, De Laat M et al. Nerve root sleeve injections in patients with failed back surgery syndrome: A comparison of three solutions. Clin J Pain 1999; 15: 132-135.

166. Kolsi I, Delecrin J, Berthelot JM et al. Efficacy of nerve root versus interspinous injections of glucocorticoids in the treatment of disc-related sciatica. A pilot, prospective, randomized, double-blind study. Joint Bone Spine 2000; 67:113-118.

167. Buttermann GR. Epidural steroid vs discectomy for lumbar disc herniation: A prospective randomized study. Presented at the $66^{\text {th }}$ Annual Meeting, American Academy of Orthopaedic Surgeons, Anaheim, CA, February 1999.

168. Lutz GE, Vad VB, Wisneski RJ. Fluoroscopic transforaminal lumbar epidural steroids: An outcome study. Arch Phys Med Rehabil 1998; 79:1362-1366.

169. Vad V, Bhat A, Lutz G, Camissa F. Transforaminal epidural steroid injections in lumbosacral radiculopathy; $A$ prospective randomized study. Spine 2002; 27:11-16.

170. Berger O, Dousset V, Delmer O et al. Evaluation of the efficacy of foraminal infusions of corticosteroids guided by computed tomography in the treatment of radicular pain by foraminal injection. J Radiol 1999; 80:917-925.

171. Melzer A, Seibel RM. Magnetic resonance (MR)-guided percutaneous pain therapy of degenerative spinal diseases. Semin
Interv Radiol 1999; 16:143-150.

172. Sequeiros RB, Ojala RO, Klemola R et al. MRI-guided periradicular nerve root infiltration therapy in low-field (0.23-T) MR system using optical instrument tracking. Eur Radiol 2002; 12:1331-1337.

173. Zennaro H, Dousset V, Viaud B et al. Periganglionic foraminal steroid injections performed under CT control. Am J Neuroradiol 1998; 19:349-352.

174. Grönemeyer DH, Gevargez A, Schindler O et al. CT-guided periradicular injections of corticosteroids in the management of lumbar radiculopathy associated with disk herniation. J Radiol 2001; 1-12.

175. Buttermann GR. Lumbar disc herniation regression after successful epidural steroid injection. J Spin Dis Tech 2002; 15: 469-476.

176. Schmid G, Vetter S, Gottmann D et al. CTguided epidural/perineural injections in painful disorders of the lumbar spine: Short- and extended-term results. Cardiovasc Intervent Radiol 1999; 22:493-498.

177. Grönemeyer D, Seibel R, Schindler $O$ et al. Microinvasive CT guided periradicular therapy for treatment of chronical functional disorders of the spine. Weiner Medizinische Wochenschrift 1995; 145:129139.

178. Devulder J. Transforaminal nerve root sleeve injection with corticosteroids, hyaluronidase, and local anesthetic in the failed back surgery syndrome. J Spinal Disord 1998; 11:151-154.

179. Slipman CW, Lipetz JS, Jackson HB et al. Therapeutic selective nerve root block in the nonsurgical treatment of atraumatic cervical spondylotic radicular pain: A retrospective analysis with independent clinical review. Arch Phys Med Rehabil 2000; 81:741-746.

180. Lutze M, Stendel R, Vesper J et al. Periradicular therapy in lumbar radicular syndromes: Methodology and results. Acta Neurochir 1997; 139:719-724.

181. Uhlenbrock D, Arlinghaus J. Results of CTguided periradicular pain therapy. Rofo Fortschr Geb Rontgenstr Neuen Bildgeb Verfahr 1997; 166:528-534.

182. Le Chevallier PL, Videgrain M, Roulleau P et al. Injection of the sacrolumbar roots: A complementary method of staging sciatica. 18 cases. Rev Rhum Mal Osteoartic 1978; 45:473-477.

183. Weiner BK, Fraser RD. Foraminal injection for lateral lumbar disc herniation. J Bone Joint Surg 1997; 79-B:804-807.

184. Narozny M, Zanetti M, Boos N. Therapeutic efficacy of selective nerve root blocks in the treatment of lumbar radicular leg pain. Swiss Med Wkly 2001; 131:75-80.

185. Friedman R, Li V, Mehrotra D et al. Foraminal injection of a painful sacral nerve root using an epidural catheter: Case report. Reg Anesth Pain Med 2002; 27; 214-216.

186. Rosenberg SK, Grabinsky A, Kooser C et al. Effectiveness of transforaminal epidural steroid injections in low back pain: A one year experience. Pain Physician 2002; 5 : 266-270.

187. Wang JC, Lin E, Brodke DS et al. Epidural injections for the treatment of symptomatic lumbar herniated discs. J Spinal Disord \& Tech 2002; 15:269-272.

188. Waldman SD. Complications of cervical epidural nerve blocks with steroids: A prospective study of 790 consecutive blocks. Reg Anesth 1989; 14:149-151.

189. Katz JA, Lukin R, Bridenbaugh PO et al. Subdural intracranial air: An unusual cause of headache after epidural steroid injection. Anesthesiology 1991; 74:615.

190. Mateo E, Lopez-Alarcon MD, Moliner S et al. Epidural and subarachnoid pneumocephalus after epidural technique. Eur J Anesthesiol 1999; 16:413-417.

191. MacLean CA, Bachman DT. Documented arterial gas embolism after spinal epidural injection. Ann Emerg Med 2001; 38:592595.

192. Williams KN, Jackowski A, Evans PJ. Epidural haematoma requiring surgical decompression following repeated cervical epidural steroid injections for chronic pain. Pain 1990; 42:197-199.

193. Reitman CA, Watters W. Subdural hematoma after cervical epidural steroid injection. Spine 2002; 27:E174-E176.

194. Waldman SD. Cervical epidural abscess after cervical epidural nerve block with steroids (Letter). Anesth Anal 1991; 72: 717.

195. Mamourian AC, Dickman CA, Drayer BP et al. Spinal epidural abscess: Three cases following spinal epidural injection demonstrated with magnetic resonance imaging. Anesthesiology 1993; 78:204.

196. Knight JW, Cordingley JJ, Palazzo MG. Epidural abscess following epidural steroid and local anesthetic injection. Anaesthesia 1997; 52:576-578.

197. Vijayan N, Dreyfus PM. Chemical epidural abscess: Case report. J Neurol Neurosurg Psychiatry 1971; 34:297-299.

198. Kaul S, Meena AK, Sundaram C et al. Spinal extradural abscess following local steroid injection. Neurol India 2000; 48:181183.

199. Elias M. Cervical epidural abscess following trigger point injection. J Pain Symptom Manage 1994; 9:71-72.

200. Chan ST, Leung S. Spinal epidural abscess following steroid injection for sciatica: Case report. Spine 1989; 14:106-108.

201. Goucke CR, Graziotti P. Extradural abscess following local anaesthetic and steroid injection for chronic low back pain. Brit J Anesth 1990; 65:427-429.

202. Yamaguchi M, Kawakubo A, Ide R et al. Epidural abscess associated with epidural block in a patient with immunosuppressive disease. Jpn J Anesthesiol 1999; 48: 506-508.

203. Sowter MC, Burgess NA, Woodsford PV et al. Delayed presentation of an extradural abscess complicating thoracic extradural 
analgesia. Br J Anaesth 1992; 68:103-105.

204. Vos PE, de Boer WA, Wurzer JA et al. Subdural hematoma after lumbar puncture: two case reports and review of the literature. Clin Neurol Neurosurg 1991; 93:127132.

205. Tekkok IH, Carter DA, Brinker R. Spinal subdural hematoma as a complication of immediate epidural blood patch. Can J Anaesth 1996; 43:306-309.

206. Sabel M, Felsberg J, Neuen-Jacob E et al. Enlargement of a chronic aseptic lumbar epidural abscess by intraspinal injections - a rare cause of progressive paraparesis. Zentralbl Neurochir 2000; 61:111114.

207. Gutknecht DR. Chemical meningitis following epidural injections of corticosteroids (Letter). Am J Med 1987; 82:570.

208. Williamson JA. Inadvertent spinal subdural injection during attempted spinal epidural steroid therapy. Anaesth Intens Care 1990; 18:406-408.

209. Lubenow T, Keh-Wong E, Kristof $K$ et al. Inadvertent subdural injection: A complication of an epidural block. Anesth Analg 1988; 67:175-179.

210. Siegfried RN. Development of complex regional pain syndrome after a cervical epidural steroid injection. Anesthesiology 1997; 86:1394-1396.

211. Dreskin S, Bajwa ZH, Lehmann L et al. Polymyoclonus resulting from possible accidental subdural injection of local anesthetic. Anesth Analg 1997; 84:692-693.

212. Kardash K, Morrow F, Béiqque F. Seizures after epidural blood patch with undiagnosed subdural hematoma. Reg Anesth Pain Med 2002; 27:433-436.

213. Rovira E, Garcia-Escrig M, Catala J et al. Chronic adhesive arachnoiditis following epidural paramethasone. Revista de Neurologia 1997; 25:2067-2068.

214. Ling C, Atkinson PL, Munton CF. Bilateral retinal hemorrhages following epidural injection. Br J Ophthalmol 1993; 77:316.

215. Young WF. Transient blindness after lumbar epidural steroid injection. Spine 2002; 27:E476-E477.

216. Kusher FH, Olson JC. Retinal hemorrhage as a consequence of epidural steroid injection. Arch Opthalmol 1995; 113:309313.

217. Purdy EP, Gurjit SA. Vision loss after lumbar epidural steroid injection. Anesth Analg 1998; 86:119-122.

218. Kao LY. Bilateral serous retinal detachment resembling central serious chorioretinopathy following epidural steroid injection. Retina 1998; 18:479-481.

219. Slipman CW, Shin CH, Patel RK et al. Persistent hiccup associated with thoracic epidural injection. Am J Phys Med Rehabil 2001; 80:618-621.

220. Slipman CW, Chow DW, Lenrow DA. Dysphonia associated with epidural steroid injection: A case report. Arch Phys Med Rehabil 2002; 83:1309-1310.

221. Sandberg DI, Lavyne MH. Symptomatic spinal epidural lipomatosis after local epidural corticosteroid injections: Case report. Neurosurgery 1999; 45:162-165.

222. Trattner A, Hodak E, David M et al. Kaposi's sarcoma with visceral involvement after intraarticular and epidural injections of corticosteroids. J Am Acad Dermatol 1993; 29:890-894.

223. Knight CL, Burnell JC. Systemic side-effects of extradural steroids. Anaesthesia 1980; 35:593-594.

224. Jacobs S, Pullan PT, Potter JM et al. Adrenal suppression following extradural steroids. Anaesthesia 1983; 38:953-956.

225. Boonen S, Van Distel G, Westhovens R et al. Steroid myopathy induced by epidural triamcinolone injection. Brit / Rheumatol 1995; 34:385.

226. Maillefert JF, Aho S, Huguenin MC et al. Systemic effects of epidural dexamethasone injections. Revue du Rhumatisme 1995; 62:429-432.

227. Ward A, Watson J, Wood P et al. Glucocorticoid epidural for sciatica: Metabolic and endocrine sequelae. Rheumatology 2002; 41:68-71.

228. Manchikanti L, Pampati V, Beyer C et al. The effect of neuraxial steroids on weight and bone mass density: A prospective evaluation. Pain Physician 2000; 3:357366.

229. Houten JK, Errico TJ. Paraplegia after lumbosacral nerve root block: Report of three cases. The Spine Journal 2002; 2:70-75.

230. Sullivan WJ, Willick SE, Chira-Adisai W et al. Incidence of intravascular uptake in lumbar spinal injection procedures. Spine 2000; 25:481-486.

231. Furman MB. Incidence of intravascular uptake in transforaminal lumbar epidural steroid injections. Spine 2000; 25:26282632.

232. Botwin KP, Gruber RD, Bouchlas CG et al. Complications of fluoroscopically guid ed transforaminal lumbar epidural injections. Arch Phys Med Rehabil 2000; 81: 1045-1050.

233. Elias M. A rare cause of radiculopathy following transforaminal epidural steroid injection. Pain Clinic 1998; 11:159-16o.

234. Cousins MJ. An additional dimension to the efficacy of epidural steroids. Anesthesiology 2000; 93:565.

235. Brouwers PJ, Kottink EJ, Simon MA et al. A cervical anterior spinal artery syndrome after diagnostic blockade of the right C6 nerve root. Pain 2001; 91:397-399.

236. Nash TP. Comment on A cervical anterior spinal artery syndrome after diagnostic blockade of the right C6-nerve root. Pain 2001; 91:217-218.

237. Stohr M, Mayer K. Nerve-root damage from local injections. Dtsch Med Wochen schr 1976; 101:1218-1220.

238. Milhaud D, Heroum C, Charif M et al. Dural puncture and corticotherapy as risks factors for cerebral venous sinus thrombosis. Eur J Neruol 2000; 7:123-124.

239. Bromage RP, Benumof JL. Paraplegia following intracord injection during attempted epidural anesthesia under general anesthesia. Reg Anesth Pain Med 1998; 23: 104-107.

240. Hodges SD, Castleberg RL, Miller T et al. Cervical epidural steroid injection with intrinsic spinal cord damage. Two case reports. Spine 1998; 23:2137-2142.

241. Pounder D, Elliott S. An awake patient may not detect spinal cord puncture. Anaesthesia 2000; 55:194

242. Delaney TJ, Rowlingson JC, Carron $\mathrm{H}$ et al. Epidural steroid effects on nerves and meninges. Anesth Analg 1980; 58:610-614.

243. MacKinnon Se, Hudson AR, Gentilli R et al. Peripheral nerve injection injury with steroid agents. Plast Reconstr Surg 1982; 69: 482-489.

244. Chino N, Awad EA, Kottke FJ. Pathology of propylene glycol administered by perineural and intramuscular injection in rats. Arch Phys Med Rehab 1974; 55:33-38.

245. Benzon HT, Gissen AJ, Strichartz GR et al. The effect of polyethylene glycol on mammalian nerve impulses. Anesth Analg 1987; 66:553-559.

246. Abram SE, Marsala M, Yaksh TL. Analgesic and neurotoxic effects of intrathecal corticosteroids in rats. Anesthesiology 1994; 81:1198-1205.

247. Latham JM, Fraser RD, Moore RJ et al. The pathologic effects of intrathecal betamethasone. Spine 1997; 22:1558-1562.

248. Robustelli della Cuna FS, Mella M, Magistrali $\mathrm{G}$ et al. Stability and compatibility of methylprednisolone acetate and ropivacaine hydrochloride in polypropylene syringes for epidural administration. Am J Health Syst Pharm 2001; 58:1753-1756.

249. Swai EA, Rosen M. An attempt to develop a model to study the effects of intrathecal steroids. Eur J Anaesthesiol 1986; 3:127-136.

250. Slucky AV, Sacks MS, Pallares VS et al. Effects of epidural steroids on lumbar dura material properties. J Spin Disord 1999: 12:331-340 